\title{
Colon-targeted delivery of live bacterial cell biotherapeutics including microencapsulated live bacterial cells
}

\author{
Satya Prakash \\ Aleksandra Malgorzata \\ Urbanska \\ Biomedical Technology and Cell \\ Therapy Research Laboratory, \\ Departments of Biomedical \\ Engineering and Physiology, Artificial \\ Cells and Organs Research Center, \\ Faculty of Medicine, McGill University, \\ Montreal, Quebec, Canada
}

\begin{abstract}
There has been an ample interest in delivery of therapeutic molecules using live cells. Oral delivery has been stipulated as best way to deliver live cells to humans for therapy. Colon, in particular, is a part of gastrointestinal (GI) tract that has been proposed to be an oral targeted site. The main objective of these oral therapy procedures is to deliver live cells not only to treat diseases like colorectal cancer, inflammatory bowel disease, and other GI tract diseases like intestinal obstruction and gastritis, but also to deliver therapeutic molecules for overall therapy in various diseases such as renal failure, coronary heart disease, hypertension, and others. This review provides a comprehensive summary of recent advancement in colon targeted live bacterial cell biotherapeutics. Current status of bacterial cell therapy, principles of artificial cells and its potentials in oral delivery of live bacterial cell biotherapeutics for clinical applications as well as biotherapeutic future perspectives are also discussed in our review.
\end{abstract}

Keywords: biotherapeutics, probiotic, microcapsules, gastrointestinal tract, colon, oral delivery, immobilization, artificial cells, bacterial cells

\section{Introduction}

In the past decade the field of gastrointestinal (GI)-related diseases has received ample interest. Physicians treating GI disorders had to face new challenges during recent years. On the one hand GI-related problems are growing rapidly within the population, especially in older patients and those with the following disorders: diarrhea, irritable bowel disease, pouchitis, Crohn's disease or ulcerative pouchitis; on the other hand; efficient and safe treatment has yet to arrive. By increasing the cost of medical care there has been an obvious need for a more reliable treatment method of higher efficacy. GI research is constantly working on exploring new techniques, designing new systems, and discovering new ways of delivering certain drugs of interest to the target organs. In particular, GI cancers pose major public health problems in the United States as well as most western countries. There are six main diseases associated with colon: Crohn's disease (ileitis or enteritis), diverticulitis, ulcerative colitis, irritable bowel syndrome (IBS), colonic dismotility, and colon cancer.

A significant health care burden is associated with IBS, with increased out-patient services, abdominal and pelvic surgeries, and GI- and non-GI-related physician visits and health care costs. Functional GI disorders such as functional dyspepsia, IBS, and other chronic medical conditions like gastroesophageal reflux disease and asthma impact significantly the patient's health-related quality of life. Impaired health-related quality of life has been demonstrated, in particular, in patients with moderate to severe disease seen in referral settings. Although the quality of life appears to improve in treatment responders, or correlates with symptom improvement, with at least some treatment modalities studied in functional gastrointestinal disorders it still required 
further studies. The significance of psychological factors such as early adverse life events or symptoms related to visceral perception such as pain and chronic stress further contribute to impairment of health-related quality of life in patients with functional GI disorders. The presence of extraintestinal symptoms appears to have a major if not greater impact on health care visits, excess health care costs, and health-related quality of life in patients with functional GI disorders (Chang 2004).

This review covers state of the art methods and technologies for targeted GI delivery of oral live cells, with in depth coverage of live cell biotherapeutics used in treatment of various GI disorders. In addition, the potential and limitations as well as future perspectives are discussed.

\section{Colon, an ideal place for action of biotherapeutics molecules - overview of GI tract and its molecular basis}

Esophagus, stomach, duodenum, small intestine (ileum), large intestine (colon), appendix, liver, gallbladder and pancreas all comprise a gut by forming a tube connection between mouth and anus through which food passes. GI tract (GIT) is a tubular passage made of muscle and mucous membrane that extends about 8.3 meters in length. Colon, a tube-like organ is made of 4 sections: the ascending colon, transverse colon, the descending colon, the sigmoid colon and it is about 1.5 to 2 meters long. Its primary function is to absorb water and salts from undigested foods and store the waste-products until excreted. The colon is viewed as the preferred absorption site for oral administration of protein and peptide drugs because of the relatively low proteolytic enzyme activities in the colon (Yang et al 2002).

The flora of the GIT in mammals is highly complex and diverse. The normal intestinal immune system is under a balance in which proinflammatory and antiinflammatory cells and molecules are carefully regulated to promote a normal host mucosal defense capability without destruction of intestinal tissue (Hahm et al 2001). Once this careful regulatory balance is disturbed, nonspecific stimulation and activation can lead to increased amounts of potent destructive immunological and inflammatory molecules being produced and released. The concept of balance and regulation of normal mucosal immune and inflammatory events is indicative of how close the intestine is to developing severe inflammation. The normal intestinal mucosal immune system is constantly stimulated by lumenal contents and bacteria (MacDermott 1996). 95\% of bacteria residing in GIT are obligate anaerobes with species like: Bifidobacterium, Clostridium, Eubacterium, Fusobacterium, Peptococcus, Peptostreptococcus, and Bacteroides and 10\% is made of facultative anaerobes: Lactobacillus, Escherichia coli, Klebsiella, Streptococcus, Staphylococcus, and Bacillus. It has been estimated that there are approximately $10^{12}$ viable bacteria per gram of large bowel content in humans, with the presence of at least 400 to 500 species (Simon and Gorbach 1984; Berg 1996). The stimulatory molecules present in the intestinal lumen that activate and induce subsequent mucosal immunologic and inflammatory events include bacterial cell wall products, such as peptidoglycans and lipopolysaccharides, as well as other chemotactic and toxic bacterial products that are produced by the many different types of bacteria within the GIT (MacDermott 1996).

The complex intestinal human defense system consists of innate and adaptive immune systems, which further are composed of intraluminal breakdown like gastric acid, pancreatic enzymes and bile as well as prevention of adhesion like intestinal motility and mucus layer. The intestinal motility, when disturbed, may promote bacterial overgrowth. The layer of mucus holds an important nonimmune gut barrier role. It forms two compartments: viscoelastic gel and superficial hydrosoluble layer which are composed of water, mucin glycoproteins and lipids. Mucus can also act as an antioxidant and counteract inflammatory mediators and byproducts (Neutra and Forstner 1987; Lichtenberger 1995). Its main functions include physical and epithelial barrier with intercellular tight junctions and constant cell turnover, a site for glycoproteins to compete with gut surface for bacterial or antigen binding as well as a site which favors bacterial colonization.

The mucous layer and mucin production are qualitatively and quantitatively altered in many situations of intestinal stress, including the inflammatory bowel diseases (IBD) (Neutra and Forstner 1987), ulcerative colitis (UC), and Crohn's disease (Corfield et al 2000). For example, in the active phase of the disease, UC patients exhibit reductions in the thickness of the colonic mucous layer, in the number of mucus-containing goblet cells, and in ex vivo analyzed MUC2 production (the main secreted-colonic mucin) (Faure et al 2005). The intricate system of digestive tract to restrict its potentially harmful contents is further made of the epithelial layer with presence of intercellular tight junctions as well as expression of adherence factors on the surface (Viswanathan and Hecht 2000). The tight junctions provide protection of the intercellular spaces and restrict the passage via the extra 
cellular pathway. Any perturbation of the intestinal barrier may lead to promotion of bacterial adherence. For instance, a study revealed a redistribution of the tight junctional transmembrane protein upon infection with Campylobacter jejuni which is a leading cause of human enterocolitis and is associated with postinfectious complications, including IBS and Guillain-Barre syndrome (MacCallum et al 2005; Chen et al 2006c). The adherence factors are expressed on the surface of epithelial cells. For instance, Helicobacter pylori has been identified as such agent which once attached to the epithelial surface initiates infection. Although a number of specific adhesins has been identified, other $H$. pylori virulence factors may play a role in adherence to gastric epithelial cells directly or through interaction with other adhesions (Zhang et al 2002). The presence of adherence factors is genetically determined but the expression can be modified (Ho et al 2005). Pattern recognition receptors (PRRs) play a role in allowing innate immune cells to distinguish between "self" and microbial "nonself" based on the recognition of broadly conserved pathogen-associated molecular patterns (PAMPs) (Kabelitz and Medzhitov 2007). Toll-like receptors (TLRs) comprise a class of transmembrane PRRs which play a role in microbial recognition, induction of antimicrobial genes, and the control of adaptive immune responses (Werling and Jungi 2003).

Figure 1 summarizes briefly the concept of TLRs. TLRs are expressed in epithelial cells of the skin, respiratory, intestinal, and genitourinary tracts that form the first protective barrier to invading pathogens (Sandor and Buc 2005). TLRs activate downstream effectors through adaptors that contain Toll/interleukin-1 receptor (TIR) domains, but the mechanisms accounting for diversification of TLR effector functions are unclear (Häcker et al 2006). The adaptive immune system is composed of gut-associated lymphoid tissue (GALT) and epithelial cells. The cellmediated branch of the adaptive immune response relies

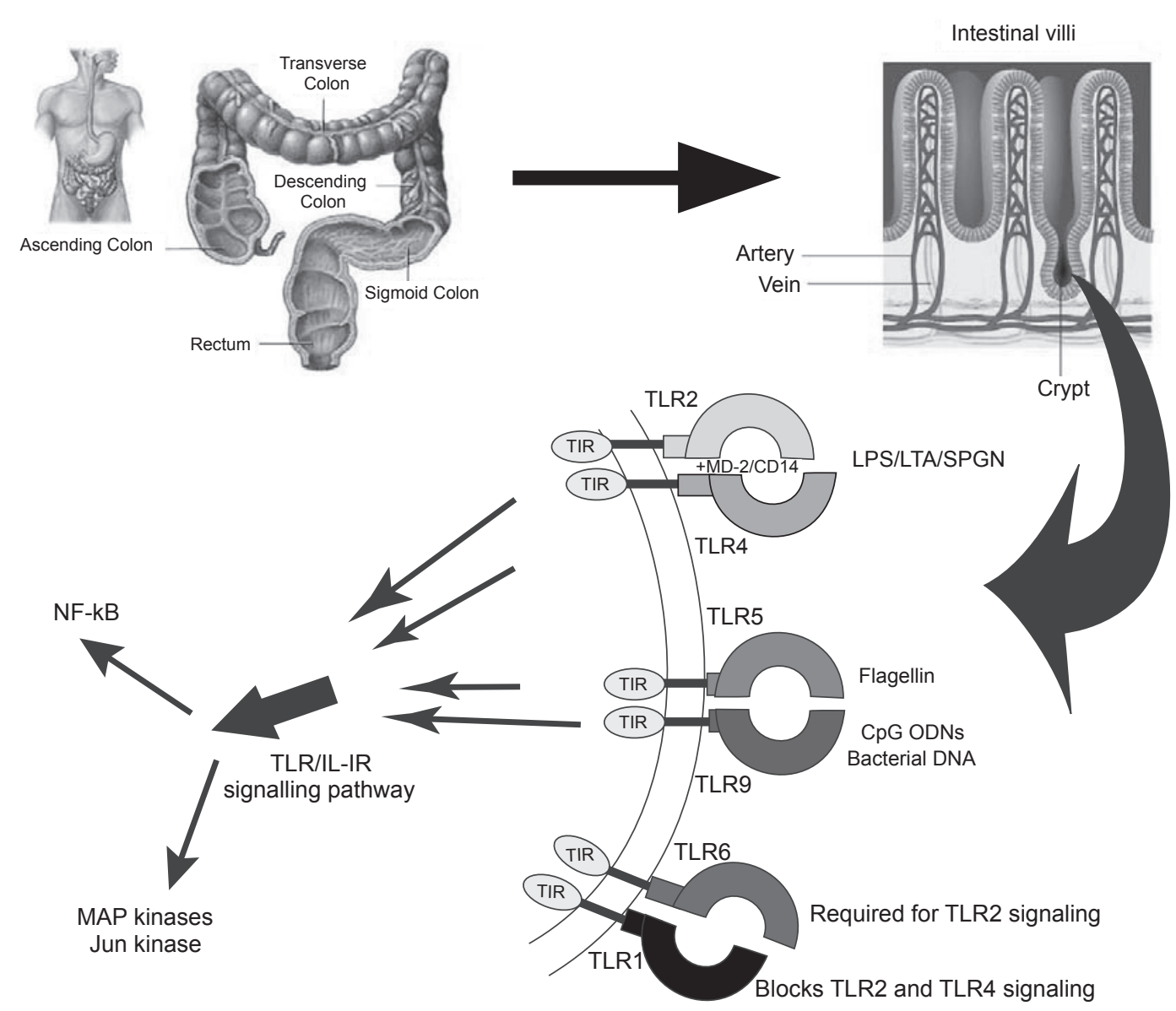

Figure I Schematic representation of molecular toll-like receptors (TLRs) of the human gastrointestinal (GI) tract which act as sensors and are the first responders in the major pathway by which the immune system detects infection or damaged tissue. Their biological function makes them attractive targets for designing various biotherapeutic molecules for such disorders as inflammation, infections, autoimmunity, allergies and cancer. 
on mucosal $\mathrm{T}$ lymphocytes and the humoral defense is composed of B lymphocytes and plasma cells secreting IgA molecules. The lymphocytes are located in organized structures like Peyer's patches and isolated lymphoid follicles. The follicle-associated epithelium (FEA) spans the lymphoid structures of Peyer's patch and consists of cubical enterocytes (FEA cells) and M cells. M-cells are responsible for sampling of particulate microbial material (Hathaway and Kraehenbuhl 2000). It has been found that $M$ cells get damaged and increased in inflamed human ileal mucosa (Cuvelier et al 1993). More detailed description of molecular composition of GIT is beyond the scope of this review.

Due to high complexity of the microbiota and the limitation of widely used culture-based techniques, the dynamic changes in the composition of the normal GIT microbial species in immunocompetent hosts during aging, between genders, and after experimental infection with microbial pathogens are still not well understood (Ge et al 2006).

\section{Colon-specific drug delivery - methods and limitations}

The old school colonic drug delivery approaches included four methods, namely, prodrugs, $\mathrm{pH}$ - and time-dependent systems, and microflora-activated systems. The continuous effort to establish new improved techniques of drug delivery yielded methods like pressure-controlled colon delivery capsules (PCDCs), CODES, colonic drug delivery system based on pectin and galactomannan coating, and Azo hydrogels. These approaches bear features like improved in vivo site specificity, versatile drug release kinetics, feasibility of the manufacturing process and design rationale to accommodate different therapeutic needs. These have been extensively described by Yang and colleagues (2002). Other methods include: pro-drugs, timed-released systems, coating of $\mathrm{pH}$-dependant polymer and the use of polysaccharides.

Novel approaches in colon-specific delivery system have been proposed like: a microbially triggered colon-targeted osmotic pump (MTCT-OP) (Liu et al 2007), TARGIT technology with application of $\mathrm{pH}$-sensitive coatings onto injection-moulded starch capsules (Watts and Smith 2005), cross-linked microspheres of guar gum studied by Chourasia and Jain (2004) in delivery of metronidazole and nanoparticles which are claimed to be able to deliver drugs to the inflammation site in severe cases of IBD where state-of-theart delivery devices fail (Lamprecht et al 2005).

\section{Various GI diseases and their treatment limitations Collagenous colitis}

Collagenous colitis (CC) is primarily a disorder of middle-aged women and is characterized on biopsy by increased subepithelial collagen as well as increased inflammatory cells in the lamina propria and increased intraepithelial lymphocytes. Approximately $10 \%$ of lymphocytic colitis patients have a positive family history of some type of inflammatory intestinal disease, including UC, Crohn's disease, CC, and celiac disease. Lymphocytic colotis is a subtype of collagenous colitis and it is characterized by chronic nonbloody watery diarrhea. Therapy in lymphocytic colitis is less well studied, but the same medications are used with success, including budesonide and high dose bismuth subsalicylate (Lazenby 2005). Other drugs used include prednisolone and Boswellia serrata extract. A study by Duncan and colleagues (1997) clearly implied that the treatment of patient with prednisolone may cause the collagenous colitis.

\section{Diarrhea}

Drug-induced diarrhea is a relatively frequent adverse event, accounting for about $7 \%$ of all adverse effects of drug therapy, being more frequent in the elderly because of factors related to the aging process itself and the higher frequency of drug therapy (Chassany et al 2000). More than 700 drugs have been implicated in causing diarrhea, which can appear a long time after the start of drug treatment, sometimes up to several months or years, and the diagnosis can be unrecognized (Spreux et al 1993). In the case-control study by Fernandez-Banares and colleagues (2006) patients consumed a variety of drugs such as prednisone, diuretics, omeprazole, low-dose aspirin, bisphosphonates, and many more. The results revealed that the usage of selective serotonin reuptake inhibitors (SS-RIs) and statins significantly related to the risk of chronic diarrhea (Fernandez-Banares et al 2006).

\section{Microscopic colitis}

Microscopic colitis is a term used to define those entities characterized by chronic watery diarrhea, normal radiological and endoscopic appearance, and microscopic abnormalities in the colon. The entity includes $\mathrm{CC}$ and lymphocytic colitis (LC) (Chang et al 2005). Various studies include the following treatments: bismuth subsalicylates, budesonide, prednisolone, Boswellia serata, cholestyramine, and 5-aminosalicylic acid agents (Abdo and Beck 2003). Insofar, the treatment with budesonide looks promising, however, the 
evidence for benefit with bismuth subsalicylate is weaker. Moreover, the effectiveness of prednisolone, Boswellia serrata extract and other therapies for induction or maintenance of remission of colitis is unknown and requires further study (Chande et al 2006).

\section{Gastritis caused by Helicobacter pylori}

Helicobacter pylori is a Gram-negative, spiral bacterium that colonizes the gastric mucosa of at least $50 \%$ of the world's population and plays a causative role in the development of chronic gastritis as well as in gastric and duodenal ulcers (Velin et al 2005). This infection also represents a high risk factor in mucosa-associated lymphoid tissue lymphomas and gastric adenocarcinomas (Blaser and Parsonnet 1994; Czinn and Nedrud 1997). Treatment regiments to eliminate gastric $H$. pylori infection are based on the association of two antibiotics and an antisecretory agent, most often a proton pump inhibitor. In a single-center randomized study the effect of high-dose intravenous proton pump inhibitor (omeprazole) alone (group 1) with omeprazole in combination with a low-dose prostaglandin analog (misoprostol; group 2) on clinical outcomes in patients with aspirin/ nonsteroidal antiinflammatory drug (NSAID)-induced upper GI bleeding was compared (Yilmaz et al 2007). This trial concluded that adding misoprostol $(600 \mu \mathrm{g} /$ day $)$ to standardized proton pump inhibitor treatment did not improve or change the rebleeding or mortality rates of patients with upper GI bleeding related to aspirin/NSAID use. In another study, patients with a history of upper GI bleeding who were infected with $H$. pylori and who were taking low-dose aspirin or other NSAIDs were screened (Chan et al 2001). It was found that among patients with H. pylori infection and a history of upper GI bleeding who were taking low-dose aspirin, the eradication of $H$. pylori was equivalent to treatment with omeprazole in preventing recurrent bleeding. Omeprazole turned out to be superior to the eradication of $H$. pylori in preventing recurrent bleeding in patients who are taking other NSAIDs. Sung and colleagues (1995) studied the efficacy of antibacterial therapy without medication to suppress gastric acid for the treatment of patients with $H$. pylori infection and gastric ulcers unrelated to the use of nonsteroidal agents. Patients received one-week course of antibacterial agents $(120 \mathrm{mg}$ of bismuth subcitrate, $500 \mathrm{mg}$ of tetracycline, and $400 \mathrm{mg}$ of metronidazole, each given orally four times a day) or a four-week course of omeprazole (20 mg orally per day). As a result, in patients with $H$. pylori infection and gastric ulcers unrelated to the use of NSAIDs, one week of antibacterial therapy without acid suppression heals the ulcers as well as omeprazole and reduces the rate of their recurrence.

Despite the success rates of various antibiotic combinations between $50 \%-75 \%$, the antibiotic resistance and poor compliance significantly affect the effectiveness of these strategies. Furthermore, antibiotic-based therapies are not suited for large-scale eradication in populations like middle age individuals in emergent societies whose life expectancy changes, with a concomitant increased gastric cancer risk (Michetti 2004).

\section{Inflammatory bowel diseases}

Today, the IBD, which include Crohn's disease and UC, affects 1 million people in the United States alone (Marx 2007). In the thorough study by Pierik and colleagues (2006) the following common drugs in treatment of IBDs, UC, and Crohn's disease were analyzed: sulfasalazine and mesalazine, azathioprine (AZA) and 6-mercaptopurine (6-MP), methotrexate (MTX), glucocorticosteroids, and infliximab.

Various case reports suggest a relation between side effects like leukopenia and a mononucleosis-like syndrome and one of the slow acetylating genotypes in IBD patients treated with sulphasalazine (Ohtani et al 2003; Teshima et al 2003). Side effects are less common with mesalazine compared to sulphasalazine but there is still some concern about nephrotoxicity with long term use (Pierik et al 2006). The antiinflammatory effect of MTX therapy on IBD is not clearly known and no studies are available at this time (Pierik et al 2006). Although glucocorticosteroids are an effective therapy choice in the initial treatment of most IBD cases, a retrospective population-based American study reported $28 \%$ and 22\% steroid dependency in Crohn's disease and UC patients and $16 \%$ steroid resistance after one year of treatment (Faubion et al 2001). In addition, several studies report a high frequency of steroid resistance of Caucasian IBD patients and high surgical interventions (Munkholm et al 1994; Reinisch et al 1995; Faubion et al 2001).

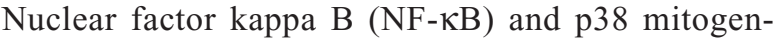
activated protein kinase pathways (MAPK) have been shown to be present in rheumatoid arthritis and inflammatory bowel disease lesions and are therefore interesting targets for pharmacological intervention (Marok et al 1996; Thiele et al 1999; Schett et al 2000; Waetzig et al 2002). NF- $\kappa$ B constitutes a ubiquitously expressed family of inducible dimeric transcription factors that regulate the expression of many genes whose encoded products prominently affect immune functions and cell death 
decisions (Karin et al 2004). Target genes of NF-кB can be categorized as inhibitors of apoptosis, promoters of cell proliferation and inflammatory mediators (Karin and Delhase 2000). Studies show that aminosalicylates and corticosteroids, used to treat IBD, inhibit cytokine-induced activation of NF- $\kappa$ B. Sulfasalazine blocks activity of the IKK complex in intestinal epithelial cells, and mesalamine has been reported to have similar effects (Wahl et al 1998). Moreover, mesalamine can also inhibit phospohorylation of the p 65 subunit of NF- $\kappa \mathrm{B}$, a post-translational modification that is essential for its transcriptional activity (Egan et al 1999). Corticosteroids have been shown to block NF-кB activation in a number of different mechanisms, including transcription upregulation of $\mathrm{I} \kappa \mathrm{B} \alpha$, an important endogenous inhibitor of $\mathrm{NF}-\kappa \mathrm{B}$, and through competition for limiting pools of essential transcriptional co-activators, such as p300 (Auphan et al 1995). In addition to these drugs that can directly inhibit NF- $\kappa \mathrm{B}$ activation, antibodies against tumor necrosis factor- $\alpha$ can also limit NF- $\kappa \mathrm{B}$ activity by neutralizing this cytokine, which is a potent activator of NF- $\kappa \mathrm{B}$. While all of these mechanisms have been studied in in vitro experiments, it is not established to what extent NF- $\mathrm{KB}$ inhibition is the precise molecular mechanism that underlies the beneficial effects of any of these drugs in vivo. In terms of MAPK pathways, currently there is a controversy whether there is a significant activation of MAPK pathways in experimental murine colitis or in human inflammatory bowel disease. So far the results to assess if MAPK inhibitors might be beneficial in inflammatory bowel disease have been inconsistent and several trials failed to demonstrate efficacy (ten Hove et al 2002; Hollenbach et al 2004, 2005; Malamut et al 2006).

In addition to NF- $\mathrm{B}$ and $\mathrm{p} 38 \mathrm{MAPK}$, the peroxisome proliferator activated receptor- $\gamma(\operatorname{PPAR} \gamma)$ is a nuclear receptor controlling the expression of a large number of regulatory genes in lipid metabolism and insulin sensitisation, as well as in inflammation and cell proliferation (Debril et al 2001; Fajas et al 2001). The role of this receptor in gut homeostasis has been described in numerous articles and it has been linked with such conditions as IBD, Crohn's disease, UC, colitis and ileitis (Sokolowska et al 2005; Slattery et al 2005; Koh et al 2006; Sastre et al 2006). In the study by Ramakers and colleagues (2007), mice were gavaged with PPAR $\gamma$ agonists prior to colitis induction. Animals were treated with rosiglitazone and after 16 days impairment of colitis was observed. This positive outcome initiated further testing, this time in clinical trials. In the study by Lewis and colleagues (2001), the efficacy of rosiglitazone was tested on
15 patients with mild to moderately active UC. Thirteen of 15 patients were receiving concomitant therapy with corticosteroids and/or immunomodulator medications. There was a decrease observed in disease with clinical and endoscopic remission ( $27 \%$ and $20 \%$, respectively) or part response $(27 \%)$ in eight patients. This study in IBD patients led to new clinical trials in IBD with these chemical compounds, and may lead to the development of safer PPAR- $\gamma$ agonist with topical effects and targeting selectively the colon (Dubuquoy et al 2000).

\section{Colon cancer}

Colorectal cancer is the most common cancer in Western countries and the second leading cause of cancer-related deaths. Colorectal cancer is the second leading cause of cancer-related deaths in the United States, accounting for nearly 60,000 deaths each year (Jemal et al 2006). In addition, at least 100 million patients in the USA and Canada have recurrent long-term GI problems. According to the National Cancer Institute, cancer of the colon is the second leading cancer diagnosis among both women and men in United States. Sporadic lesions represent 75\%-80\% of all colorectal cancer, whereas $20 \%-25 \%$ are in younger individuals or in patients with a family history of cancer, suggesting a heritable susceptibility (Rodriguez-Moranta and Castells 2005). Although there have been recent advances in adjuvant therapy, there are no major breakthroughs in the treatment of colorectal cancers. Animal studies have provided important insights into the etiology of colon cancer, but there have been no major advances in the prevention of this disease. For instance, pancreatic cancer still contributes to high mortality rates since the average survival time after its detection is less than one year. The lack of treatment is due to no advances made in understanding the cause of this disease.

A recent in vitro study investigated a new drug for treatment of metastatic colorectal cancer, irinotecan (CPT-11) (Le et al 2006). The cytotoxic effect of the new drug was evaluated alone and in combination with mitomycin $\mathrm{C}(\mathrm{MMC})$ and hyperthermia on three colorectal cancer cell lines: CACO-2, HT-29, and DHD/K12/TRb (PROb). It was found that the combination of CPT-11 and MMC had a large spectrum of cytotoxicity in in vitro models. This indicates that a clinical use of intraperitoneal chemohyperthermia with MMC and CPT-11 to treat colorectal peritoneal carcinomatosis of colorectal origin was designed. However, further in vivo studies need to confirm these findings. 
In vitro and in vivo studies tested the effect of combined therapy with demethylating agent 5-aza-2'-deoxycytidine (DAC) and irinotecan (CPT-11) on the human colon cancer cell line HCT-15 (Ishiguro et al 2006). It was postulated that DAC might increase the tumor sensitivity to chemotherapy through demethylation and restoration of gene expression. It was concluded that pretreatment with low-dose DAC may have the potential to be used as a "biosensitizer" of DNAdamaging agents such as CPT-11 when the apoptotic pathway is inactivated as a result of aberrant promoter methylation in the cancer.

There are some studies indicating that regular use of NSAIDs may be associated with decreased colorectal cancer risk (Peleg et al 1994, 1996; Reeves et al 1996; Chan et al 2005). However, the studies did not take into consideration whether the lowering of the cancer incidence was due to tumors of the proximal or distal colon. In a study by Mahipal and colleagues (2006), the impact of NSAIDs on the proximal and distal colon was evaluated. The study found statistically not significant association between either distal colon or rectal cancer and aspirin or nonaspirin NSAID use. Unfortunately, the use of NSAID drugs like aspirin, whether enteric- or nonenteric-coated, leads to side effects like GI bleeding (Kelly et al 1996; Rao 1997; Banoob et al 2002) and digestive complications (Lanas 2001; Sibilia et al 2003). A comprehensive review on aspirin-related GI side-effects and the mechanism by which aspirin causes GI damage was published by Hochain and colleagues (2000).

Although much has been learned about the incidence of colorectal cancer in patients who have IBD and its correlation with disease activity, duration, and anatomic location; almost no data are available regarding specific therapeutic considerations during adjuvant or palliative chemotherapy for these patients with respect to their underlying disease (Goessling and Mayer 2006). Today the adjuvant therapy for colorectal cancer consists primarily of combinations of 5-fluorouracil/leucovorin (5-FU/LV) (with infusional or bolus 5-FU) with oxaliplatin or oral capecitabine. In addition, bevacizumab, the angiogenesis inhibitor and cetuximab the epidermal growth factor receptor inhibitor are supplemented (de Gramont et al 2006). In depth results of Phase III trials of infusional 5-fluorouracil/leucovorin and oxaliplatin (FOLFOX) as a new standard of care in the palliative and adjuvant treatment of colorectal cancer have been summarized in a review by Grothey and Goldberg (2004). In addition to already mentioned pharmacologic treatments, the nonpharmacologic ones are being widely tested as well and reported to modestly alter sporadic adenoma recurrence rates in randomized trials. These include calcium (Heaney 2006), folic acid (Larsson et al 2006), and selenium (Gonzalez and Salas-Salvado 2006). Table 1 summarizes the above GI diseases and their treatment limitations.

\section{Limitations}

Dyspepsia, nausea, vomiting, diarrhea, and constipation are just few of many side effects increasingly seen in patients taking GI drugs (Leong and Chan 2006). Mucosal ulceration that can manifest as GI hemorrhage, stricture, and perforation are examples.

In one study, 1.4 million people aged 66 years and older were examined for upper GI hemorrhage in British Columbia and Ontario (Mamdani et al 2006). It was observed that patients treated with selective cyclooxygenase-2 (COX-2) inhibitors had increased upper GI hemorrhage. Although in a recent report by Lanas and Ferrandez (2006) we find out that selective cyclooxygenase-2 (COX-2) inhibitors (coxibs) are safer to the GIT than traditional NSAIDs, they may increase the incidence of serious cardiovascular adverse events (CVEs). In addition, coxib therapy is more expensive than combination therapy using a nonselective NSAID and a proton-pump inhibitor (Hur et al 2006). Another study clearly states that NSAIDs produce symptoms of dyspepsia and peptic ulcer disease in up to $50 \%$ and up to $20 \%$, respectively, of individuals taking them (Peura 2004).

Nonsteroidal antiinflammatory drug toxicity in the upper GIT is the most common serious drug-induced toxicity reported to drug regulatory authorities. While differences exist between NSAIDs and aspirin, most studies have shown that advanced age, history of peptic ulcer disease, serious concomitant illnesses, and coprescription of NSAID/aspirin with anticoagulants and steroids are high risk factors. The use of potent antiulcer therapy, treatment of $H$. pylori infection and the development of COX-2 inhibitor will change the scenario of NSAID/aspirin-related GI toxicity in the next millennium (Sung et al 2000).

To sum up, many promising fields have already contributed to a better understanding of some of the underlying mechanisms of GI diseases. By means of pharmacogenetics, molecular genetics, introduction of immune-modulators and monoclonal antibodies and other techniques great advances have been made in the management of the above diseases. However, a curative safe therapy does not yet exist. Due to the presence of specific bacterial populations in the colon 
Table I Various gastrointestinal diseases and their treatment limitations

\begin{tabular}{|c|c|c|c|}
\hline Disease & Proposed treatment & $\begin{array}{l}\text { Potential adverse } \\
\text { symptoms/problems }\end{array}$ & References \\
\hline Collagenous colitis & $\begin{array}{l}\text { Prednisolone } \\
\text { Boswellia serrata }\end{array}$ & $\begin{array}{l}\text { Accumulation of lymphocytes } \\
\text { in the colonic epithelium and } \\
\text { connective tissue } \\
\text { Thickening of the subepithelial } \\
\text { collagen table }\end{array}$ & $\begin{array}{l}\text { Duncan et al 1997; Lazenby } \\
2005\end{array}$ \\
\hline Diarrhea & $\begin{array}{l}\text { Prednisolone } \\
\text { Omeprazole } \\
\text { Asprin } \\
\text { Bisphosphonates }\end{array}$ & $\begin{array}{l}\text { Frequent watery, loose bowel } \\
\text { movements } \\
\text { Damage to the mucosal lining } \\
\text { An inhibition of absorption }\end{array}$ & $\begin{array}{l}\text { Spreux et al 1993; } \\
\text { Chassany et al 2000; } \\
\text { Fernandez-Banares et al } \\
2006\end{array}$ \\
\hline Microscopic colitis & $\begin{array}{l}\text { Bismuth subsalicylates } \\
\text { Budesonide } \\
\text { Prednisolone } \\
\text { Boswellia serrata } \\
\text { Cholestyramine } \\
\text { 5-aminosalicylic acid }\end{array}$ & $\begin{array}{l}\text { Profuse watery diarrhea } \\
\text { Higher incidence of immune } \\
\text { diseases }\end{array}$ & $\begin{array}{l}\text { Abdo and Beck 2003; Chang } \\
\text { et al 2005; Chande et al } 2006\end{array}$ \\
\hline Gastritis & $\begin{array}{l}\text { Omeprazole } \\
\text { Aspirin } \\
\text { Mistoprostol } \\
\text { Tetracycline } \\
\text { Metronidazole }\end{array}$ & $\begin{array}{l}\text { Antibiotic resistance } \\
\text { Gastric ulcers } \\
\text { Gastrointestinal bleeding } \\
\text { Recurrent abdominal pain } \\
\text { Increased gastric cancer risk }\end{array}$ & $\begin{array}{l}\text { Sung et al 1995; Chan et al } \\
200 I ; \text { Michetti 2004; Yilmaz } \\
\text { et al } 2007\end{array}$ \\
\hline Inflammatory bowel disease & $\begin{array}{l}\text { Sulfasalazine } \\
\text { Mesalazine } \\
\text { Azathioprine } \\
\text { 6-mercaptopurine } \\
\text { Methotrexate } \\
\text { Glucocorticosteroids } \\
\text { Infliximab }\end{array}$ & $\begin{array}{l}\text { Leukopenia } \\
\text { Mononucleosis-like syndrome } \\
\text { Nephrotoxicity } \\
\text { Steroid resistance which leads } \\
\text { to surgical interventions }\end{array}$ & $\begin{array}{l}\text { Munkholm et al I994; } \\
\text { Reinisch et al I995; Faubion } \\
\text { et al 200I; Ohtani et al 2003; } \\
\text { Teshima et al 2003; Pierik } \\
\text { et al } 2006\end{array}$ \\
\hline Colon cancer & $\begin{array}{l}\text { Irinotecan (CPT-II) } \\
\text { Mitomycin C (MMC) } \\
\text { 5-aza-2'-deoxycytidine (DAC) } \\
\text { irinotecan (CPT-II) } \\
\text { NSAID } \\
\text { 5-fluorouracil/ leucovorin } \\
\text { (5-FU/LV) } \\
\text { Oxaliplatin Capecitabine }\end{array}$ & $\begin{array}{l}\text { Toxicity } \\
\text { Gastrointestinal bleeding } \\
\text { Digestive complications } \\
\text { Temporary effect on bone } \\
\text { marrow } \\
\text { Hair loss } \\
\text { Anemia } \\
\text { Overall fatigue } \\
\text { May increase cardiovascular } \\
\text { adverse events } \\
\text { Lowered resistance to } \\
\text { infections } \\
\text { No data about specificity } \\
\text { of treatments }\end{array}$ & $\begin{array}{l}\text { Kelly et al I996; Rao I997; } \\
\text { Banoob et al 2002; Sibilia } \\
\text { et al 2003; Grothey and } \\
\text { Goldberg 2004; de Gramont } \\
\text { et al 2006; Ishiguro et al } \\
\text { 2006; Lanas and Ferrandez } \\
\text { 2006; Le et al 2006; Mahipal } \\
\text { et al } 2006\end{array}$ \\
\hline
\end{tabular}

and an apparent transient, small reversal in the otherwise increasing $\mathrm{pH}$ gradient are factors which vastly limit and delay the already extensively explored research for initiating colon-specific drug release (Yang et al 2002).

The use of drugs is still an essential part of the physician's armamentarium. However, given the evolving potential sideeffects information, physicians and patients should weigh the benefits and risks of these treatments. The drug use and drug coverage policies should be more restrictive; although limiting access to drugs and their potential benefits may protect the population from adverse drug effects as well as the need to routinely reassess patients' health.

\section{Delivery of bacterial cells currently used for treating GI specific diseases}

According to Doron and Gorbach (2006), a probiotic is a "live microbial food ingredients that, when ingested in sufficient quantities, exerts health benefits on the consumer". Lactic acid bacteria (LAB) are the organisms most commonly used as probiotics (Salminen et al 1998). Probiotics exert their 
benefits through several mechanisms; they prevent colonization, cellular adhesion and invasion by pathogenic organisms, they have direct antimicrobial activity and they modulate the host immune response. The strongest evidence for the clinical effectiveness of probiotics has been in their use for the prevention of symptoms of lactose intolerance, treatment of acute diarrhea, attenuation of antibiotic-associated GI side effects and the prevention and treatment of allergy manifestations.

An interesting study was performed by Galdeano and Perdignon (2004) with probiotic strains and their adherence patterns in the gut and in mucosal immune stimulation. Lactobacillus casei interaction with the gut was observed using transmission electron microscopy (TEM). The study demonstrated that only antigenic particles interact with the immune cells and their fast clearance from the gut agrees with those described for the particulate antigens.

The above study proved that regular ingestion of probiotics does not interfere with the host gut microflora but does exert health benefits on the consumer. In another study with guinea pigs the intestinal motility changes were monitored by testing 8 bacterial strains belonging to Bifidobacterium, Lactobacillus, and Streptococcus genera within the probiotic preparation VSL\#3 (VSL Pharmaceuticals Inc., Fort Lauderdale, MD, USA; VSL Pharmaceuticals 2007). The outcome revealed that the proximal colon relaxation activity showed by the probiotic bacteria could be one of the possible mechanisms of action by which probiotics exert their positive effects in regulating intestinal motility (Massi et al 2006).

Although, probiotic therapy modulates the composition of the intestinal flora and is believed to inhibit the inflammatory response, the metabolic activity of some intestinal microorganisms inhabiting the gut may lead to the production of harmful substances. These substances could be metabolically undesirable (eg, d-lactic acid for the newborn) or might lead to potentially carcinogenic substances such as $N$-nitroso compounds (Goldin 1986). Therefore a thorough assessment of specific strains as well as doses seems to be essential.

The following section summarizes numerous studies which tested probiotic bacterial strains in treatment of various diseases.

\section{Various GI diseases treated with biotherapeutics Rotavirus diarrhea, acute diarrhea, antibiotic-associated diarrhea}

There has been a great amount of research done in the field of probiotics and their effect on diarrhea. Rotavirus diarrhea is the major cause of infantile gastroenteritis worldwide and the infection is associated with approximately 600,000 deaths every year, predominantly in developing countries. A study by Chapoy (1985) and Cetina-Sauri and Sierra-Basto (1994) focused on treatment of acute diarrhea using Saccharomyces boulardii. A randomized, double-blind, placebo controlled clinical trial was conducted by Salazar-Lindo and colleagues (2004) to screen Lactobacillus casei strain GG in the treatment of infants with acute watery diarrhea. A meta-analysis was performed by Huang and colleagues (2002) to validate the efficacy of probiotic use in acute diarrhea in children where a co-administration of probiotics with standard rehydration therapy reduced the duration of acute diarrhea by approximately one day. Another study on 55 infants aged 5-24 months, was performed by Saavedra and colleagues (1994) to explore the prevention of diarrhea in hospitalized infants using Bifidobacterium lactis (BB12) and Streptococcus thermophilus. Lactobacillus $G G$ was used in prevention of nosocomial diarrhea in infants in the study by Szajewska and colleagues (2001) which concluded that a prophylactic use of Lactobacillus $G G$ significantly reduced the risk of nosocomial diarrhea in infants, particularly nosocomial rotavirus gastroenteritis. Lactobacillus reuteri and B. lactis were compared in a double-blind, placebo-controlled, randomized trial by Weizman and colleagues (2005) to screen for preventative properties of daycare illness with positive results suggesting that children supplemented with formulas with $L$. reuteri or B. lactis had fewer and shorter episodes of diarrhea, with no effect on respiratory illnesses. The effects of long-term consumption of a fermented infant formula (with Bifidobacterium breve c50 and Streptococcus thermophilus 065 was evaluated on acute diarrhea in healthy infants with the outcome that a fermented formula may reduce the severity of acute diarrhea among healthy young infants which may be linked to the bifidogenic effects of fermentation products and their interactions with the intestinal immune system (Thibault et al 2004).

A randomized placebo-controlled double-blind study with 220 hospitalized children was conducted to assess the efficacy of Lactobacillus $G G$ vs. breast-feeding in the prevention of rotavirus nosocomial infection concluding that breast feeding was more beneficial (Mastretta et al 2002). Saccharomyces boulardii and placebo were used in an antibiotic-associated diarrhea prevention randomized-controlled trial by Kotowska and colleagues (2005) with 269 children reaching positive evidence that $S$. boulardii effectively reduces the risk of antibiotic-associated diarrhea in children because only $8 \%$ had presence of diarrhea. A meta-study screening 
the efficacy of probiotics in prevention and treatment of diarrhea associated with the use of antibiotics was done using 9 randomized double-blind placebo-controlled trials with children with 4 yeast, 4 lactobacilli and 3 combination of bacteria by D'Souza and colleagues (2002) concluded that the evidence of probiotics beneficial role still needs to be proven by designing a larger scale study. Another randomized, placebo-controlled trial was conducted using the probiotic Lactobacillus rhamnosus strain $G G$ (LGG) to see if the addition of LGG to standard therapy prolonged remission in children with Crohn's disease by Bousvaros and colleagues (2005) with 75 children which resulted in median time to relapse of 9.8 months for LGG group and 11 months for placebo group. In this study the differences were not statistically significant but no benefit of probiotics was apparent (Bousvaros et al 2005). A study using L. acidophilus and $B$. infantis was conducted on 367 preterm infants in treatment of necrotizing enterocolitis by Lin and colleagues (2005) and resulted in death of 7 vs 20 a significantly lower in the study when compared with the control group. O'Mahony and colleagues (2005) studied Lactobacillus salivarius UCC4331 and Bifidobacterium infantis 35624 in 77 adult IBS patients to compare the response of symptoms and cytokine ratios after ingestion of probiotic preparations resulting in $B$. infantis reducing pain, bloating and suggesting an immune-modulating role for this organism.

\section{Gastric ulcers caused by Helicobacter pylori}

In a double-blind, randomized, controlled clinical trial, $326 \mathrm{H}$. pylori-infected school children from a low social economic area of Santiago, Chile were treated with both live and heat-killed strains of Lactobacillus johnsonii, Lactobacillus paracasei or vehicle once daily for 4 weeks. A C13-urea breath test demonstrated a significant fall in $H$. pylori colonization in children receiving live L. johnsonii, but not the other groups. Once again, this study implies a probiotic species specificity for the therapeutic effect (Cruchet et al 2003). Sheu and colleagues (2006) have screened the impact of Lactobacillus- and Bifidobacterim-containing yogurt on $H$. pylori in 138 patients. The suppression rate was improved in eradication rate by quadruple therapy of residual $H$. pylori after failed triple therapy. Another study focused on H. pylori-infected children by administration of a probiotic, Lactobacillus acidophilus and comparing its efficacy with a synbiotic, Saccharomyces boulardii plus inulin (SbI) (Gotteland et al 2005). The study concluded that $S$. boulardii may serve as an agent that fights $H$. pylori in colonized individuals. In the presence of clarithomycin-resistant $H$. pylori, eradication is significantly attenuated. An interesting randomized study was run on $85 H$. pylori patients undergoing eradication with triple therapy using the following probiotics: Lactobacillus casei subspecies rhamnosus, Saccharomyces boulardii, Lactobacillus acidophilus plus Bifidobacterium lactis or placebo (Cremonini et al 2002). As a result, all the groups given probiotics performed better than placebo group but failed to be superior to antibiotic therapy. Ushiyama and colleagues (2003) demonstrated that Lactobacillus gasseri inhibited both the in vitro growth of clarithomycin-resistant $H$. pylori and the release of IL- 8 from epithelial cells. In addition, in an in vivo mouse model, $H$. pylori colonization was significantly decreased by Lactobacillus gasseri. Another inhibitory effect was demonstrated by Chatterjee and colleagues (2003) in a study with Lactobacillus acidophilus on $H$. pylori growth. In addition to studies screening the efficacy of probiotic strains in treatment of H. pylori infection, another study confirmed a positive impact that Lactobacillus $G G$ has on GI side-effects caused by H. pylori antibiotic therapy (Armuzzi et al 2001). The above studies support the complementary effect of probiotics in the management of $H$. pylori infection.

The role of $H$. pylori in the management of nonulcer dyspepsia produced numerous $H$. pylori eradication regimens, but despite many studies no perfect therapy has been identified so far. The American College of Gastroenterology has published a set of guidelines for the treatment and prevention of NSAID-induced ulcers (Lanza 1998). This contains a well-motivated, practical approach to the problem of NSAID ulceration; emphasizes the "risk profile" approach to selection of patients for prophylaxis; and presents compelling arguments against the routine use of $\mathrm{H}_{2}$-receptor antagonists for NSAID prophylaxis. The role of $H$. pylori is also addressed. Screening for $H$. pylori infection in NSAID users is not currently recommended, but patients with past or present ulceration who need NSAID therapy should also receive eradication therapy (Louw and Marks 1999). Lau and colleagues () questioned the conventional wisdom that surgery is indicated for peptic ulcer rebleeding.

\section{Inflammatory bowel disease}

Inflammatory bowel disease (IBD) is a chronic disease of the digestive tract, and usually refers to two related conditions, namely UC and Crohn's disease, characterized by chronic and spontaneously relapsing inflammation. Although the etiology of IBD is still insufficient, there is increasing experimental evidence to support a role for luminal bacteria 
in the initiation and progression of these intestinal conditions; probably related to an imbalance in the intestinal microflora, relative predominance of aggressive bacteria and insufficient amount of protective species (Fiocchi 1998; Shanahan 2000). The current hypothesis in the pathogenesis of the chronic idiopathic IBD, Crohn's disease, and UC, suggests that these are caused by an overly aggressive cell-mediated immune response to luminal commensal bacteria in genetically susceptible hosts (Sartor 2004; Shanahan 2005). In addition, IBDs are multifactorial processes and clinical and animal studies indicate that emotional stress may contribute to the onset and progress of these diseases. On the other hand, enhanced free radical production in mucosal cells has been also implicated in the pathogenesis of IBD (Colon et al 2004). This disease was described for the first time in 1952 (Crohn et al 1952) and today, it has been estimated that at least 3.5 million Americans visit their physicians each year for IBD which accounts for $25 \%$ of all patients seen in gastroenterologists' practice, with 15,000-30,000 new cases being diagnosed each year (Everhart and Renault 1991). Crohn's disease is most common in the developed countries of Europe, Scandinavia, and the US and generally is thought to be more common in whites (Sandler and Golden 1986).

In the systematic review by Inadomi and colleagues (2003) it was estimated that $£ 45.6$ million was spent annually in the UK for IBD care, translating into approximately $£ 90$ annually in costs per patient. On the other hand, the annual mean direct costs of caring for IBS patients in Canada were estimated to be US\$260 (Bentkover et al 1999).

A primary goal in treating CD is to control GIT inflammation. Currently, the treatment of this disease is based on its degree of inflammation and consists of dietary adjustments, surgery and various medications including antiinflammatory drugs, steroids, immunosuppressants, antibiotics, antitumor necrosis factor (anti-TNF) drugs, antidiarrheals and other symptom suppressing drugs. However, an ideal treatment is yet to be found (Caprilli et al 2002; Gruner et al 2002). As in other inflammatory processes, IBD is characterized by an upregulation in the synthesis and release of different pro-inflammatory cytokines, including reactive oxygen and nitrogen metabolites, eicosanoids, platelet-activating factor, and cytokines (Stenson 1994). All of these mediators contribute to the pathogenic cascade that initiates and perpetuates the inflammatory response of the gut. As a consequence, and until its etiology has been completely elucidated, the best strategy to effectively down-regulate intestinal inflammation is to interfere with multiple stages of the inflammatory cascade, preferably with a single drug treatment (Galvez et al 2001).
Serological markers such as anti-Saccharomyces cerevisiae antibodies (ASCA) and atypical perinuclear antineutrophilic cytoplasmic antibody (atypical pANCA) have proven useful in the diagnosis and differentiation of Crohn's disease and UC (Jaskowski et al 2006).

Biologic and other novel therapies targeted to specific pathogenic processes offer the potential for improved treatment outcomes in patients with $\mathrm{CD}$ and alteration of the course of the disease (Sandborn 2001). A possible therapeutic approach in IBD therapy is the administration to these patients of probiotic microorganisms, defined as viable nutritional agents conferring benefits to the health of the human host (Peran et al 2005).

This complex interplay of genetic, microbial and environmental factors culminates in a sustained activation of the mucosal immune and nonimmune response, probably facilitated by defects in the intestinal epithelial barrier and mucosal immune system, resulting in active inflammation and tissue destruction. Under normal situations, the intestinal mucosa is in a state of 'controlled' inflammation regulated by a delicate balance of proinflammatory (TNF- $\alpha$, interferon [IFN]- $\gamma$, interleukin [IL]-1, IL-6, IL-12) and antiinflammatory cytokines (IL-4, IL-10, IL-11). The mucosal immune system is the central effector of intestinal inflammation and injury, with cytokines playing a central role in modulating inflammation (Ardizzone and Porro 2005). For inflammatory bowel diseases (IBD) the most important cytokines identified are IL-1, IL-2, IL-6, IL-8, IFN- $\gamma$, and TNF- $\alpha$ (van Hogezand and Verspaget 1996). Cytokines may, therefore, be a logical target for IBD therapy using specific cytokine inhibitors.

At present, the biological therapies that are being used in clinical practice or investigated for the treatment of IBD are predominantly proteins, usually delivered intravenously or subcutaneously. The therapies used include: 1 . TNF- $\alpha$ inhibitors: infliximab, CDP 571, etanercept, onercept, CNI-1493, and thalidomide. 2. Inhibitors of lymphocyte trafficking: natalizumab, LPD-02 and ICAM-1. 3. Inhibitors of Th1 polarization: monoclonal antibodies for IL-12, IFN- $\gamma$ and anti-IFN- $\gamma$. 4. Immunoregulatory cytokines: IL-10 and IL-11. 5. Inhibitors of NF- $\kappa B$. 6. Growth factors: epidermal growth factor (EGF) and keratinocyte growth factor (KGF) (Kurtovic and Segal 2004). Therefore, targeted molecules can be specifically eliminated in their expression directly on the transcriptional level. Interesting therapeutic trials are expected against ICAM-1 and pro-inflammatory signaling molecules (ie, NF- $\kappa \mathrm{B}$ ). The future development of immune therapies in IBD therefore holds great promises for better treatment modalities of IBD but will also open important 
new insights into a further understanding of inflammation pathophysiology (Schreiber 1998).

Current treatment of IBD is rather effective though it is only working in symptomatic fashion. Most recombinant "biologicals" have not been an overwhelming success. Infliximab has shown clinically relevant efficacy and is used in patients not responding to the standards. Alternatives such as modulating the bacterial-epithelial interaction, tightening of the mucosal barrier and maybe even immunostimulation should be studied since most recent finding on etiology and pathophysiology point to a disturbed barrier with consequent abnormal bacterial epithelial interaction as the main problem in the IBD syndrome (Scholmerich 2006).

There is currently a growing appreciation for the role of the enteric flora in health and disease. In the past years overwhelming evidence has accumulated for the role of commensal gut bacteria in the IBD, Crohn's disease, and UC. Both entities are mainly located in areas with high bacterial concentrations (Bohm and Kruis 2006).

In the last decade there were five main clinical trials that examined various probiotics, namely species of Lactobacillus, in the treatment of IBD (Halpern et al 1996; Nobaek et al 2000; O'Sullivan and O'Morain 2000; Niedzielin et al 2001; Sen et al 2002). In the past years, many reviews have been written about IBS as well as the role of microflora in IBS (Madden and Hunter 2002; Floch 2003). In a randomized controlled clinical trial, Kim and colleagues (2003) examined the effects of a probiotic formulation containing eight different probiotic species, VSL\#3 supplementing 450 billion lyophilized bacteria/day (VSL Pharmaceuticals Inc.), on GI transit and symptoms of patients with diarrhea predominantly IBS. After 10 weeks of treatment, there was no significant difference in mean GI transit measurements, bowel function scores or satisfactory global symptom relief between the two treatment groups. However, VSL\#3 appears to be a promising agent in IBS as it significantly reduced the abdominal bloating (Kim et al 2003).

The mechanism of action of probiotics in IBS remains still poorly understood due to changes and complexity in fermentation products. Another study screened for lactobacilli, bifidobacteria, Streptococcus thermophilus, enterococci, coliforms, Bacteroides and Clostridium perfringens changes in the fecal composition of 10 patients with diarrhea-predominant IBS after administration of VSL\#3 probitocs with positive results yielding no significant alterations in indigenous flora (Brigidi et al 2001). In a similar open-label study, Bazzocchi and colleagues (2002) made use of the following hypothesis: "characteristics of the luminal milieu, the relationship, the balance between luminal prokaryotic cells and mucosal eukaryotic cells and the consequent immunological and humoral local and systemic responses take part in the pathophysiology of several diseases and, consequently bacteriotherapy can play a relevant role in the treatment and prevention of IBS and more in general, of the intestinal functional disorders". He demonstrated that VSL\#3 probiotic induced changes in the composition of the colonic microflora together with improvement in colonic dysmotility and in visceral perception. On the other hand, in a double-blind, placebo-controlled, crossover, four-week trial of Lactobacillus plantarum 299V in 12 previously untreated patients the probiotic did not alter colonic fermentation or improve symptoms in comparison with placebo (Sen et al 2002). An interesting study designed to confirm the efficacy of the probiotic bacteria $B$. infantis in a large-scale, multicenter, clinical trial of women with IBS as well as to determine the optimal dosage of probiotic for administration in a freeze-dried, encapsulated formulation was performed in UK (Whorwell et al 2006). A dose of $1 \times 10(8)$ cfu was the most stable, convenient and amenable to widespread use in IBS and that $B$. infantis relieved many of the IBS symptoms. Further studies evaluated the effect of probiotics Bacillus subtilis, Streptococcus faecium in a form of Medilac DS on GI symptoms and intestinal gas volume changes in forty patients with IBS (Kim et al 2006). After 4-week treatment, it was found that both probiotics are safe and useful agents in patients with IBS. The efficacy of Lactobacillus $G G$ was screened in the randomized, double-blinded, placebo-controlled study with 50 children for 6 weeks suffering from IBS (Bausserman and Michail 2005). Although Lactobacillus $G G$ turned out not to be superior to placebo in the treatment of abdominal pain in children with IBS it still may be promising in relieving such symptoms as perceived abdominal distention. The above studies present promising options in treatment of IBS as we gain more insightful information about the disease itself as well as variety of available probiotics with beneficial properties. However, what needs to be emphasized is that these summarized results support the concept of specific probiotic strains being more effective that others across varied disease states.

\section{Collagenous colitis}

Collagenous colitis is a chronic inflammatory bowel disease that affects the colon (Wildt et al 2006a). It is also considered to be a cause of chronic diarrhea. Collagenous and lymphocytic colitis have been recognized as chronic 
intestinal inflammatory disorders causing watery diarrhea, which have been recognized in the past three to two decades, respectively. In a double-blind placebo-controlled study supervised by Wildt and colleagues (2006b) the effectiveness of probiotic treatment, namely: Lactobacillus acidophilus and Bifidobacterium animalis subsp. lactis has been screened in patients with collagenous colitis. The study concluded that probiotic treatment may potentially influence the disease course of collagenous colitis. In another trial, the therapeutic clinical benefit was found of probiotic E. coli strain Nissle 1917 (EcN) in patients with collagenous colitis (Tromm et al 2004).

\section{Intestinal diseases caused by Escherichia coli}

There are five types of E. coli, enterotoxigenic, enteropathogenic, enteroadherent, enteroinvasive, and enterohemorrhagic E. coli, which are responsible for as much as $25 \%$ of all diarrheal diseases in developing countries. They tend to be transmitted via contaminated foods, particularly weaning foods, and water (Niyogi et al 1994). In an in vitro study, the effect of probiotic Lactobacillus casei $G G$ (LGG) was tested to find out that it has the effect of reducing the rate of $E$. coli $\mathrm{C} 25$ (E. coli $\mathrm{C} 25$ ) translocation. The study was performed using an in vitro cell-culture model with human colonic carcinoma (Caco-2) enterocytes. It was concluded that the probiotic bacterium $L G G$ inhibits bacterial translocation of $E$. coli $\mathrm{C} 25$ in a dose-dependent manner in an in vitro cell-culture model (Mattar et al 2001). In the study by Akil and colleagues (2006) with 24 children a commercial capsule or powder containing $S$. boulardii was administered once a day for 5 days to screen for the number of $E$. coli colonies in the colon. It was found that $S$. boulardii may be effective in reducing the number of $E$. coli colonies in stool which may lead to preventative treatment of urinary tract infections.

\section{Colorectal cancer}

Colorectal cancer, whether sporadic or hereditary, is caused by a defined set of molecular events (Tejpar and Van Cutsem 2002). Germline mutations in tumorsuppressor adenomatous polyposis coli (APC) genes and DNA mismatch repair (MMR) genes lead to the recognized familial adenomatous polyposis (FAP)-related colorectal cancer and the hereditary non-polyposis colorectal cancer (HNPCC), respectively (Sandborn 2001). Bacterial flora keeps the normal colon mucosa in a continuous state of low-grade inflammation, stimulating release of various pro-inflammatory cytokines by the immune cells (Rhodes and Campbell 2002).

Anastomotic leakage of colonic and rectal anastomoses is a major complication after an intraperitoneal large-bowel anastomosis in patients with colorectal malignancy and after large intestine surgery. It is associated with a $6 \%-22 \%$ mortality rate. Many factors influence the healing of colon anastomoses. Flavonoids have been recognized for centuries as physiologically active constituents that are used to treat human diseases (Inan et al 2006).

Anal sphincter function is increasingly preserved following rectal excision for cancer and provides a better quality of life for patients than does a permanent colostomy. However, anastomotic complications may cause considerable morbidity and mortality (Dehni et al 1998).

The use of probiotics in prevention and cancer treatment has been undergoing a recent evaluation in a number of studies. Although we should not expect miraculous outcomes in cancer treatment following probiotics administration, their immunomodulatory properties have been tested and need to be brought to publics' attention. In the study by McIntosh and colleagues (1999) Lactobacillus acidophilus (Delvo Pro LA-1), Lactobacillus rhamnosus (GG), Bifidobacterium animalis (CSCC1941), and Streptococcus thermophilus (DD145) strains were examined for their influence on 1,2-dimethylhydrazine (DMH)induced intestinal tumors in 100 male Sprague-Dawley rats when added as freeze-dried bacteria. This study concluded that the strain of L. acidophilus supplied as freeze-dried bacteria in the diet was protective because it significantly inhibited tumors within the rat colon. There is a substantial amount of studies done by Perdignon dealing with antiinflammatory properties of probiotic bacteria. For instance, the probiotic bacterium Lactobacillus casei was screened for its influence on the expression of receptors involved in the innate immune response in colorectal cancer BALB/c model mice (Galdeano and Perdigon 2006). Further, a complex nature of kefir was studied in BALB/c mice. Kefir is fermented milk produced by the action of lactic acid bacteria, yeasts and acetic acid bacteria, trapped in a complex matrix of polysaccharides and proteins. In addition, it is an excellent source of proteins and calcium (Vinderola et al 2005). A conclusion was drawn that since different components of kefir have an in vivo role as oral biotherapeutic substances capable of stimulating immune cells of the innate immune system they are able to downregulate the Th2 immune phenotype or to promote cell-mediated immune responses against tumors and also against intracellular pathogenic 
infections (Vinderola et al 2006). Another kefir-related study was done by Vinderola and colleagues (2005) which was the first in vivo study to determine the immunomodulating capacity of kefir on the intestinal mucosal immune response in mice of viable or heat-inactivated bacteria at different doses. The adjuvant immunomodulatory effect of kefir was tested in rats, young and old (Thoreux and Schmucker 2001). An enhanced in vitro antibody secretion by cultured lymphocytes isolated from the Peyer's patches and the intestinal lamina propria were found only in young rats indicating that the administration of kefir to young rats has a beneficial effect on intestinal mucosal immune response against cholera toxin.

Probiotics are useful in a variety of diarrheal diseases and may be useful in inflammatory and allergic disorders. Table 2 summarizes the above described diseases and lists

Table 2 Various pathological conditions treated with viable microorganisms (bacteria or yeasts) - probiotics

\begin{tabular}{|c|c|c|c|c|c|}
\hline Disease & $\begin{array}{l}\text { Biotherapeutics } \\
\text { used }\end{array}$ & $\begin{array}{l}\text { Live bacterial } \\
\text { cell optimal dose }\end{array}$ & Mode of delivery & $\begin{array}{l}\text { Potential site } \\
\text { of action }\end{array}$ & References \\
\hline Rotavirus diarrhea & $\begin{array}{l}\text { Lactobacillus GG } \\
\text { Lactobacillus reuteri } \\
\text { Lactobacillus acidophilus } \\
\text { Lactobacillus bulgaricus } \\
\text { Bifidobacterium bifidum } \\
\text { Streptococcus } \\
\text { thermophilus } \\
\text { Saccharomyces boulardi } \\
\text { Lactobacillus casei } \\
\text { Bifidobacterum bulgaris }\end{array}$ & $\begin{array}{l}\sim 10^{10} / \mathrm{d} \\
\sim 10^{9} / \mathrm{d} \\
\sim 10^{10} / \mathrm{d} \\
\sim 10^{8} / \mathrm{ml} \\
\sim 10^{10} / \mathrm{d} \\
500 \mathrm{mg} / \mathrm{d} \\
500 \mathrm{mg} / \mathrm{d} \\
\sim 10^{10} / \mathrm{d} \\
\sim 10^{10} / \mathrm{d}\end{array}$ & $\begin{array}{l}\text { Capsules } \\
\text { Foods }\end{array}$ & $\begin{array}{l}\text { Small and large } \\
\text { intestines }\end{array}$ & $\begin{array}{l}\text { Saavedra et al I994; } \\
\text { Szajewska et al 200I; } \\
\text { D'Souza et al 2002; } \\
\text { Huang et al 2002; } \\
\text { Mastretta et al 2002; } \\
\text { Salazar-Lindo et al 2004; } \\
\text { Thibault et al 2004; } \\
\text { Guandalini, } 2006\end{array}$ \\
\hline $\begin{array}{l}\text { Antibiotic associated } \\
\text { diarrhea }\end{array}$ & $\begin{array}{l}\text { Saccharomyces boulardi } \\
\text { Lactobacillus GG }\end{array}$ & $\begin{array}{l}500 \mathrm{mg} / \mathrm{d} \\
\sim 10^{10} / \mathrm{d}\end{array}$ & $\begin{array}{l}\text { Capsules } \\
\text { Foods }\end{array}$ & $\begin{array}{l}\text { Small and large } \\
\text { intestines }\end{array}$ & $\begin{array}{l}\text { D'Souza et al 2002; } \\
\text { Kotowska et al } 2005\end{array}$ \\
\hline Radiation induced diarrhea & $\begin{array}{l}\text { VSL\#3 (Lactobacillus } \\
\text { casei, Lactobacillus } \\
\text { plantarum, Lactobacillus } \\
\text { acidophilus, Lactobacillus } \\
\text { delbruekii ssp. bul- } \\
\text { garicus, Bifidobacterium } \\
\text { longum, Bifidobacterium } \\
\text { breve, Bifidobacterium } \\
\text { infantis and Streptococ- } \\
\text { cus thermophilus) }\end{array}$ & $4.5 \times 10^{9} / 2$ capsules & Capsules & $\begin{array}{l}\text { Small and large } \\
\text { intestines }\end{array}$ & Delia et al 2002 \\
\hline $\begin{array}{l}\text { Helicobacter pylori } \\
\text { colonization/gastric ulcers }\end{array}$ & $\begin{array}{l}\text { Lactobacillus johnsonni } \\
\text { Saccharomyces boulardi } \\
\text { Lactobacillus acidophilus } \\
\text { Lactobacillus gasseri }\end{array}$ & $\begin{array}{l}\sim 10^{10} / \mathrm{d} \\
500 \mathrm{mg} / \mathrm{d} \\
\sim 10^{10} / \mathrm{d} \\
\sim 10^{8} / \mathrm{d}\end{array}$ & Capsules & $\begin{array}{l}\text { Stomach, } \\
\text { duodenum, } \\
\text { small and large } \\
\text { intestines }\end{array}$ & $\begin{array}{l}\text { Cruchet et al 2003; } \\
\text { Chatterjee et al 2003; } \\
\text { Ushiyama et al 2003; } \\
\text { Gotteland et al 2005; } \\
\text { Sheu et al } 2006\end{array}$ \\
\hline $\begin{array}{l}\text { Inflammatory bowel disease } \\
\text { (IBD) }\end{array}$ & $\begin{array}{l}\text { Escherichia coli Nissle } \\
\text { Saccharomyces boulardi } \\
\text { VSL\#3 } \\
\text { Lactobacillus GG }\end{array}$ & $\begin{array}{l}500 \mathrm{mg} / \mathrm{d} \\
\sim 10^{1 \%} / \mathrm{d}\end{array}$ & Capsules & Small intestines & Bousvaros et al 2005 \\
\hline Ulcerative Colitis & Escherichia coli Nissle & & Capsules & $\begin{array}{l}\text { Small and large } \\
\text { intestines }\end{array}$ & $\begin{array}{l}\text { Halpern et al 1996; } \\
\text { Langman and Allan 1999; } \\
\text { Rembacken et al } 1999\end{array}$ \\
\hline Irritable bowel syndrome & $\begin{array}{l}\text { Lactobacillus plantarii } \\
\text { Bifidobacterium infantis }\end{array}$ & $\begin{array}{l}\sim 10^{10} / \mathrm{d} \\
\sim 10^{10} \mathrm{~d}\end{array}$ & Capsules & $\begin{array}{l}\text { Small and large } \\
\text { intestines }\end{array}$ & $\begin{array}{l}\text { Halpern et al I996; } \\
\text { O'Sullivan and O'Morain, } \\
\text { 2000; Nobaek et al } \\
\text { 2000; Brigidi et al 200I; } \\
\text { Niedzielin et al 200I; } \\
\text { Bazzocchi et al 2002; Sen } \\
\text { et al 2002; O'Mahony } \\
\text { et al } 2005\end{array}$ \\
\hline
\end{tabular}


Table 2 (Continued)

\begin{tabular}{|c|c|c|c|c|c|}
\hline Disease & $\begin{array}{l}\text { Biotherapeutics } \\
\text { used }\end{array}$ & $\begin{array}{l}\text { Live bacterial } \\
\text { cell optimal dose }\end{array}$ & Mode of delivery & $\begin{array}{l}\text { Potential site } \\
\text { of action }\end{array}$ & References \\
\hline Collagenous colitis & $\begin{array}{l}\text { Lactobacillus acidophilus } \\
\text { Bifidobacterium animalis } \\
\text { subsp. Lactis }\end{array}$ & $\begin{array}{l}\sim 10^{1 \%} / \mathrm{d} \\
\sim 10^{10} \mathrm{~d}\end{array}$ & $\begin{array}{l}\text { Capsules } \\
\text { Injections }\end{array}$ & Large intestines & Wildt et al 2006b \\
\hline Colorectal cancer & $\begin{array}{l}\text { Lactobacillus acidophilus } \\
\text { Lactobacillus rhamnosus } \\
\text { Bifidobacterium animalis } \\
\text { Streptococcus } \\
\text { thermophilus } \\
\text { Lactobacillus casei }\end{array}$ & & $\begin{array}{l}\text { Capsules } \\
\text { Milk } \\
\text { Kefir }\end{array}$ & Large intestines & $\begin{array}{l}\text { Mclntosh et al I999; } \\
\text { Thoreux and Schmucker } \\
\text { 2001; Vinderola et al } \\
\text { 2005, 2006; Galdeano } \\
\text { and Perdigon } 2006\end{array}$ \\
\hline
\end{tabular}

biotherapeutics used in their treatment, their dose, mode of delivery and potential site of action. In Table 3 , a proposed mechanism of action is described along with marketed probiotic-containing products. It is important to note that the effects are strain- and dose-specific and therefore more clinical studies are needed to be designed screening each strain and disorder. Other problems that probiotic production may encounter include: oxygen stress due to agitation during $\mathrm{pH}$ control, oxygen and pressure stresses during centrifugation or filtration, membrane damages during freeze-drying due to freezing itself and due to the drying step. In addition, such situations like production of inhibitory compounds by starter cultures, heating-pasteurization, freezing, food additives (salt, spices, flavors) and drying could further alter viability of probiotic species. However, probiotics appear to be safe, as it was shown in treatment with infants.

\section{Microencapsulated live oral biotherapeutics, their potential and limitations}

It was Lim and Sun (1980) who invented alginate-polyL-lysine-alginate (APA) microcapsule in 1980 and ever since microencapsulation has been proven to be an effective strategy for cell implantation and cell-based gene therapy for the treatment of diabetes, metabolic or neurologic, disorders, and cancer (Ross et al 2000; Sambanis 2003; Basta et al 2004; Luca et al 2005). As it was noted before, to obtain an efficient colon targeting biotherapeutics, the delivered materials need to be protected from the GI

Table 3 Biotherapeutics, gastroenteric pathogens and their proposed mechanism of action and current marketed biotherapeutics products

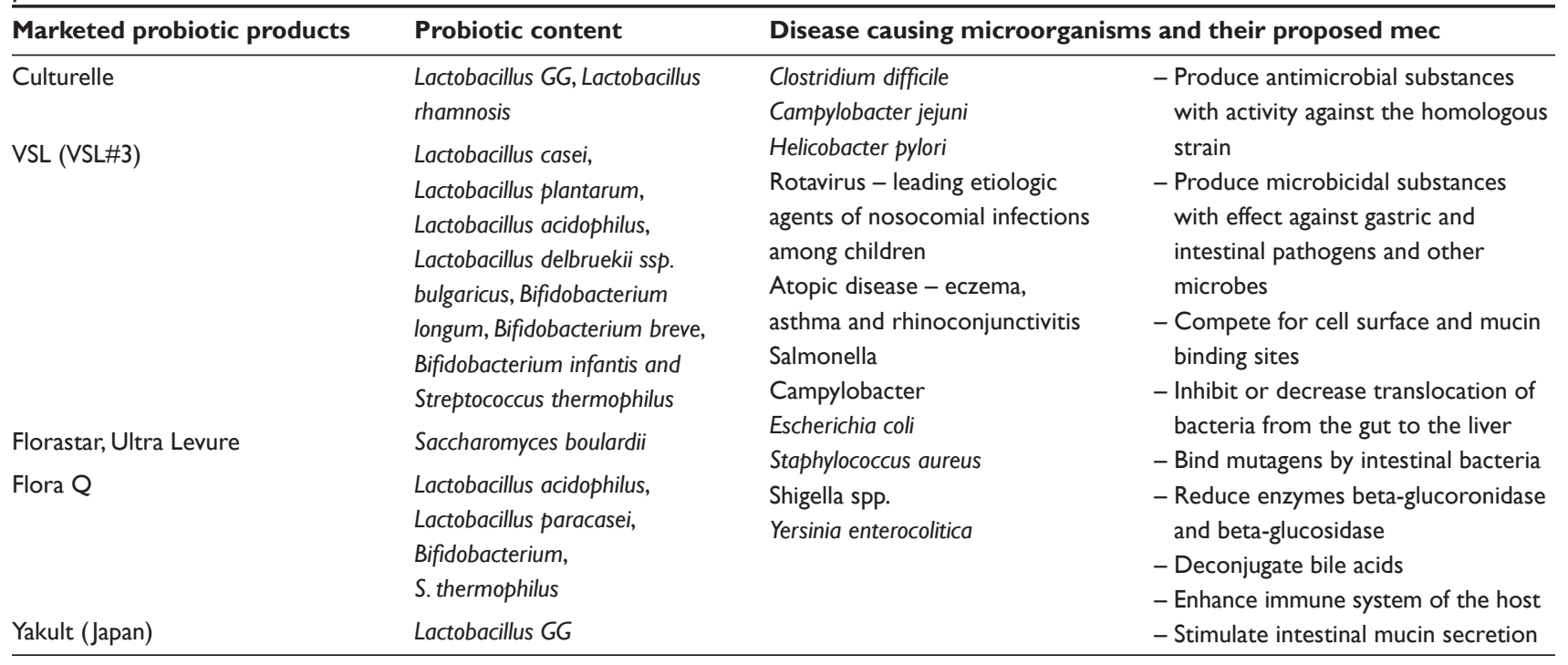


environment and remain functionally unaltered on arrival to the site.

As mentioned earlier, in order for any microorganism be able to stimulate the gut immune system, for instance probiotic bacteria, they should be resistant to the enzymes in the oral cavity (amylases and lysozyme), to the low acidic $\mathrm{pH}$ in the stomach and to the presence of bile acids, pancreatic juice and mucus in the small intestine. These properties are important for survival in the small and large bowel. Micro-organisms must also be able to persist within the GIT and to adhere to gut epithelial tissue. Another important consideration expressed in the probiotic definition is the one concerned with the viability of the micro-organisms (Galdeano and Perdigon, 2004). Although Ouwehand and Salminen (1998) received interesting results while working on treatment for acute diarrhea suggesting that in some cases nonviable bacteria are able to produce effects similar to those obtained with viable bacteria, these findings need to be further explored and proven effective in treatment of other diseases.

\section{The principle of microencapsulation, its design and potentials in live biotherapeutics delivery}

Cell microencapsulation consists of enclosing cells, such as primary cells, cell lines and genetically engineered cells to secrete therapeutic product in a semipermeable membrane (Chang and Prakash 1997). It is a process by which a liquid or solid active ingredient (encapsulated material) is packaged within an inert material (encapsulant) to protect the microencapsulated materials from the surrounding environment, or conversely to protect the environment from the active ingredient. Artificial cells refer to manmade microscopic structures that possess some functional properties of biological cells. The membrane allows bidirectional diffusion of nutrients, oxygen, metabolites, and waste but prevents high molecular weight substances, such as antibodies and immunocytes, from entering the microcapsule, which provides an immune protection for the cells. Microcapsule membrane can be made of natural (alginate, arabinoglycan, chitosan, agarose, poly-L-lysine, xylan and collagen) or synthetic polymers (polyaminoacids, polyacrylates, chondroitin sulfate, cyclodextrin) (Zhang et al 2006). Other plant-derived polysaccharides, such as amylase, inulin, pectin and guar gum are known to remain unaffected in the presence of GI enzymes which enable the way for the formulation of the colon targeted delivery systems (Chourasia and Jain,2003). APA microencapsulation is one of the most well-studied encapsulation technologies, including entrapment of cells in alginate gel beads, formation of alginate-poly-L-lysine membrane, and liquefying of the alginate gel core to leave the cell floating in the center of the microcapsule (Ma 1994). Studies show that APA encapsulation yields intact capsules that preserve their integrity and are able to retain live bacterial cells (Urbanska et al 2006) (Figure 2). Moreover, genetically engineered bacteria have been encapsulated and used in oral therapy (Prakash and Chang 1996, 2000).

Cell microencapsulation is one of the promising strategies for the in vitro production of proteins or in vivo delivery of therapeutic products (Wen-tao et al 2006). In addition to in vitro culture, implantation of microencapsulated cells represents a promising strategy for the controlled, localized, and long-term in vivo delivery of therapeutic products to the hosts (Orive et al 2003a). Bioencapsulation has provided a range of promising therapeutic treatments for diabetes (Sun et al 1996), hemophilia (Hortelano et al 1996), cancer (Xu et al 2002), and renal failure (Prakash and Chang 1996). Although it might not serve yet as a replacement technology to existing treatment modalities, it surely can serve as an alternative method should present ones fail. Today, with its potential and greatly increasing interest, the field of microencapsulation should shortly receive an extensive scrutinization which will shortly allow its application as a complementary treatment method to already well established methods.

\section{Methods of live biotherapeutics cell delivery}

Microencapsulation technology raises great potential in delivery of biotherpeutics live cells in medicine and biotechnology. In order to maintain microencapsulated cultures properties, it needs to be enclosed in a system that provides optimal conditions for their viability targeted delivery and functionality. The microcapsules preparation include physical methods like: pan coating, air-suspension coating, centrifugal extrusion, vibrational nozzle, spraydrying and chemical methods like: interfacial polymerization, in situ polymerization, matrix polymerization.

Oral artificial bacterial cell therapy is a therapy which is based on oral delivery of live bacterial cells which are enclosed in artificial polymeric membrane. Clinical trials suggest potential beneficial effects of probiotic therapy for preventing and treating antibiotic-associated diarrhea, acute diarrhea including rotavirus-induced diarrhea, traveler's diarrhea, and diarrhea-predominant IBS. The most extensively studied probiotics for diarrhea are Lactobacillus, 


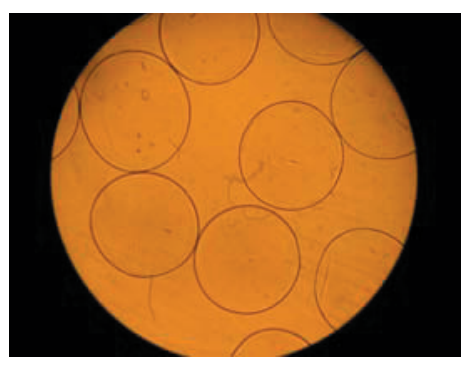

(A)

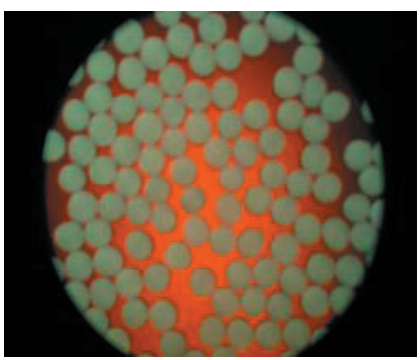

(B)

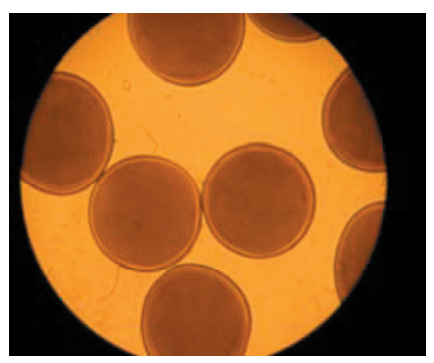

(C)

Figure 2 (a) Photomicrograph of freshly prepared empty APA microcapsules.

(Magnification 6.3x). (b) Photomicrograph of freshly prepared APA microcapsules loaded with L. acidophilus. (Magnification: 2.5x). (c) Photomicrograph of APA microcapsules loaded with L. acidophilus cells after 76 hours of incubation in MRS broth and $150 \mathrm{rpm}$ in-vitro shaking at $37^{\circ} \mathrm{C}$ (Magnification: 6.3x) 180.

Bifidobacterium and Saccharomyces, with potential mechanisms of therapeutic action based on the protection of intestinal epithelial cell and barrier function, prevention of enterotoxin binding to intestinal epithelial cells, and regulation of intestinal microbial environment (Yan and Polk 2006). The release patterns include: pressure, shear stress, melting, dissolving, solvents, enzymes, chemical reactions, hydrolysis, slow disintegration, and $\mathrm{pH}$.

The mathematical models have been built for animal cell growth, tumor cell growth (Quaranta et al 2005), such as Gompertzian growth, logistic growth, or exponential growth law (Retsky et al 1990). Various systems are listed in Table 4. Microencapsulation is a suitable technique to deliver various biotheraputics to a wide spectrum of cells and tissues enhancing the potential applicability of this strategy. Numerous applications include pharmaceuticals, dyes, agrochemicals, flavors and fragrances and other commercial possibilities.

\section{Conclusions and future perspectives}

At the start of the 21 st century, research is poised at the interphase where artificial cells now range from macrodimensions, to microndimensions, to nano-dimensions, and to molecular dimensions. Cell encapsulation represents an alternative non-viral approach for the long term delivery of therapeutic products. A comprehensive review covering delivery of live bacterial cells has been published by Prakash and Jones (2005).

Another review outlining the safety of current probiotic compounds has been published (Borriello et al 2003). Cases of infection due to lactobacilli and bifidobacteria are extremely rare, and are estimated to occur at a rate of approximately $0.05 \%-0.4 \%$ of all cases of infective endocarditis and bacteremia (Borriello et al 2003). No increase in bacteremia caused by Lactobacillus species was seen in Finland over the period from 1999 to 2000, despite an increased consumption of Lactobacillus rhamnosus GG (Isolauri et al 2002). Nevertheless, case reports have identified fungemia in two immunosuppressed patients (Riquelme et al 2003) and exacerbation of diarrhea in two patients with UC (Candelli et al 2003) who consumed Saccharomyces boulardi. Few other case reports have been published of infection caused after use of probiotics, like development of sepsis in premature neonates with short gut syndrome and chronic intestinal inflammation after consumption of Lactobacillus GG (Kunz et al 2004). Also Lactobacillus rhamnosus infection cases have been reported in elderly patients, a 74-year-old woman (Rautio et al 1999) and a 67-year-old man (Mackay et al 1999) who developed a liver abscess and tooth infection, respectively. The advantages of oral administration may result in the popularization of this mode of therapy once more data is produced about the incorporation of biologically active agents such as bacteria in therapeutics or advanced food systems and once it has been shown such option is safe and efficient.

So far, the current data is promising and raises hopes in medicine and biotechnology. However, the amount of clinical trials is still insufficient to conclude the overall safety of probiotic strains and other biotherapeutics use in therapy. Much work is still needed to exploit these benefits and to increase our understanding of their mechanisms, for instance improvement of microcapsule membrane designs, methods for improved cell harvest, the mass production of artificial cell microcapsules and the overall cost effective storage and clinical efficacy. Nevertheless, the already available data suggests that only time and additional high quality outcome studies are needed to yield more promising and convincing results. Ultimately, the efficacy, long-term 
Table 4 Microcapsule membrane systems features

\begin{tabular}{|c|c|c|}
\hline Delivery vehicles & Features & Reference \\
\hline Alginate-poly-L-lysine-alginate & $\begin{array}{l}\text { - Most studied system for encapsulation of living cells } \\
\text { - Formed by immersion of the calcium alginate beads } \\
\text { in an aqueous solution of poly-L-lysine } \\
\text { - Allows for proliferation of encapsulated cells and } \\
\text { prolongs the survival of xeno-graphs implanted } \\
\text { both intraperitoneally and subcutaneously } \\
\text { - Used for encapsulated cells in industry, medicine, } \\
\text { and agriculture, production of ethanol by yeast, } \\
\text { lactic acid by lactic acid bacteria, monoclonal } \\
\text { antibodies by hybridoma cells } \\
\text { - Tested in gene, cell and enzyme therapies } \\
\text { - Simple and safe encapsulation procedure at } \\
\text { physiological conditions } \\
\text { - Long-term in vivo applications cause graft failures }\end{array}$ & $\begin{array}{l}\text { Ma 1994; Prakash and Chang, 1996, 2000; } \\
\text { Klinkenberg et al 200I; Rokstad et al 2002; } \\
\text { van Raamsdonk et al 2002; Strand et al 2003; } \\
\text { de Groot et al 2004; Urbanska et al } 2006\end{array}$ \\
\hline Alginate-agarose microcapsules & $\begin{array}{l}\text { - Cell survival dependent on cell lines } \\
\text {-Viability maintained for more than } 70 \text { days with no } \\
\text { aggregates formation } \\
\text { - Mechanical stability compromised }\end{array}$ & Orive et al 2003a \\
\hline $\begin{array}{l}\text { Alginate-chitosan (AC) } \\
\text { microcapsules }\end{array}$ & $\begin{array}{l}\text { - Low cost } \\
\text { - Sturdier membrane than APA } \\
\text { - Improved mechanical stability and reduced cell } \\
\text { leakage } \\
\text { - Suitable for mammalian and microbial cell growth } \\
\text { and functions }\end{array}$ & $\begin{array}{l}\text { Bartkowiak and Hunkeler 1999; Gaserod } \\
\text { et al I999; Serp et al 2000; Orive et al } 2005\end{array}$ \\
\hline $\begin{array}{l}\text { Genipin cross-linked AC } \\
\text { microcapsules }\end{array}$ & $\begin{array}{l}\text { - Covalent link created by naturally occurring genipin } \\
\text { - Enhanced membrane strength and durability }\end{array}$ & Chen et al 2005, 2006a, 2006b \\
\hline Alginate-PMCG-alginate capsules & $\begin{array}{l}\text { - Improved membrane strength } \\
\text { - Easily adjusted capsule size and wall thickness } \\
\text { - Oligomeric PMCG may be cytotoxic }\end{array}$ & (Orive et al 2003b) \\
\hline $\begin{array}{l}\text { Alginate-cellulose sulfate-poly- } \\
\text { (methylene-co-guanidine) } \\
\text { (A-CS-PMCG) system }\end{array}$ & $\begin{array}{l}\text { - Improved mechanical strength } \\
\text { - Easy control over membrane thickness } \\
\text { - Oligomeric PMCG may be immunogenic } \\
\text { - Yet to test long-term stability }\end{array}$ & $\begin{array}{l}\text { Brissova et al I998; Lacik et al 1998; Nurdin } \\
\text { et al 2000; Bucko 2005; Bucko et al } 2006\end{array}$ \\
\hline $\begin{array}{l}\text { Polyvinlyamine hydrochloride-based } \\
\text { microcapsules }\end{array}$ & $\begin{array}{l}\text { - Mechanically stable } \\
\text { - Permeability can be controlled over a wide range }\end{array}$ & Grigorescu et al 2002 \\
\hline PHEMA-MMA system & $\begin{array}{l}\text { - Water insoluble } \\
\text { - Better stability and durability } \\
\text { - Limited cell survival and mass transfer in some } \\
\text { applications }\end{array}$ & $\begin{array}{l}\text { Sefton et al 2000; Vallbacka et al 200I; } \\
\text { Kovacs-Nolan and Mine } 2005\end{array}$ \\
\hline $\begin{array}{l}\text { Chitosan core-poly } \\
\text { (MAA-HEMA-MMA) shell }\end{array}$ & $\begin{array}{l}\text { - Prepared in physiological conditions } \\
\text { - Controllable mechanical strength and permeability } \\
\text { - Supported hepatocytes growth } \\
\text { - Maintained cell functions }\end{array}$ & Zhu et al 2005 \\
\hline $\begin{array}{l}\text { Collagen core complexed with } \\
\text { terpolymer HEMA-MAA-MMA-shell }\end{array}$ & $\begin{array}{l}\text { - Improved mechanical strength and chemical } \\
\text { stabilizing } \\
\text { - Enhanced cell functions }\end{array}$ & $\begin{array}{l}\text { Chia et al 2002; Yin et al 2003; Quek } \\
\text { et al } 2004\end{array}$ \\
\hline $\begin{array}{l}\text { Sodium cellulose sulfate and poly } \\
\text { (dimethyldiallylammonium chloride) } \\
\text { system ( } \mathrm{NaCD}-\mathrm{PDMDAAC} \text { ) }\end{array}$ & $\begin{array}{l}\text { - MWCO less than } 2 \text { KD if prepared by standard } \\
\text { method addition of pore forming agent (starch) } \\
\text { - Increased cutoff to } 70 \text { KD for protons } \\
\text { - Allowed secretion and release of therapeutics by } \\
\text { the encapsulated cells. }\end{array}$ & $\begin{array}{l}\text { Dautzenberg et al 1999a, 1999b; Mei and Yao } \\
\text { 2002; Zhang et al 2005; Yao et al } 2006\end{array}$ \\
\hline
\end{tabular}


safety and cost effectiveness of these therapies will prove their worth.

\section{Acknowledgments}

The authors would like to acknowledge the support of research grants from the Canadian Institute of Health Research (CIHR) and the Natural Sciences and Engineering Research Council (NSERC) of Canada. Also the help of Jasmine Bhathena with Figure 1 is acknowledged. Faculty of Medicine Internal Scholarship to Aleksandra Urbanska is acknowledged as well. The authors report no conflicts of interest in this work.

\section{References}

Abdo AA, Beck P. 2003. Diagnosis and management of microscopic colitis. Can Fam Physician, 49:1473-8.

Akil I, Yilmaz O, Kurutepe S, et al. 2006. Influence of oral intake of Saccharomyces boulardii on Escherichia coli in enteric flora. Pediatr Nephrol, 21:807-10.

Ardizzone S, Porro GB. 2005. Biologic therapy for inflammatory bowel disease. Drugs, 65:2253-86.

Armuzzi A, Cremonini F, Bartolozzi F, et al. 2001. The effect of oral administration of Lactobacillus GG on antibiotic-associated gastrointestinal side-effects during Helicobacter pylori eradication therapy. Aliment Pharmacol Ther, 15:163-9.

Auphan N, DiDonato JA, Rosette C, et al. 1995. Immunosuppression by glucocorticoids: inhibition of NF-kappa B activity through induction of I kappa B synthesis. Science, 270:286-90.

Banoob DW, McCloskey WW, Webster W. 2002. Risk of gastric injury with enteric- versus nonenteric-coated aspirin. Ann Pharmacother, 36:163-6.

Bartkowiak A, Hunkeler D. 1999. New microcapsules based on oligoelectrolyte complexation. Ann N Y Acad Sci, 875:36-45.

Basta G, Sarchielli P, Luca G, et al. 2004. Optimized parameters for microencapsulation of pancreatic islet cells: an in vitro study clueing on islet graft immunoprotection in type 1 diabetes mellitus. Transpl Immunol, 13:289-96.

Bausserman M, Michail S. 2005. The use of Lactobacillus GG in irritable bowel syndrome in children: a double-blind randomized control trial. J Pediatr, 147:197-201.

Bazzocchi G, Gionchetti P, Almerigi PF, et al. 2002. Intestinal microflora and oral bacteriotherapy in irritable bowel syndrome. Dig Liver Dis, 34(Suppl 2):S48-S53.

Bentkover JD, Field C, Greene EM, et al. 1999. The economic burden of irritable bowel syndrome in Canada. Can J Gastroenterol, 13(Suppl A):89A-96A.

Berg RD. 1996. The indigenous gastrointestinal microflora. Trends Microbiol, 4:430-5.

Blaser MJ, Parsonnet J. 1994. Parasitism by the "slow" bacterium Helicobacter pylori leads to altered gastric homeostasis and neoplasia. J Clin Invest, 94:4-8.

Bohm SK, Kruis W. 2006. Probiotics: do they help to control intestinal inflammation? Ann N Y Acad Sci, 1072:339-50.

Borriello SP, Hammes WP, Holzapfel W, et al. 2003. Safety of probiotics that contain lactobacilli or bifidobacteria. Clin Infect Dis, 36:775-80.

Bousvaros A, Guandalini S, Baldassano RN, et al. 2005. A randomized, double-blind trial of Lactobacillus GG versus placebo in addition to standard maintenance therapy for children with Crohn's disease. Inflamm Bowel Dis, 11:833-9.

Brigidi P, Vitali B, Swennen E, et al. 2001. Effects of probiotic administration upon the composition and enzymatic activity of human fecal microbiota in patients with irritable bowel syndrome or functional diarrhea. Res Microbiol, 152:735-41.
Brissova M, Lacik I, Powers AC, et al. 1998. Control and measurement of permeability for design of microcapsule cell delivery system. J Biomed Mater Res, 39:61-70.

Bucko M. 2005. Immobilization of a whole-cell epoxide-hydrolyzing biocatalyst in sodium alginate-cellulose sulfate-poly(methylene-coguanidine) capsules using a controlled encapsulation process. Enzyme Microb Technol, 36:118-26.

Bucko M, Vikartovska A, Gemeiner P, et al. 2006. Nocardia tataricans cells immobilized in sodium alginate-cellulose sulfate-poly(methylene-coguanidine) capsules: mechanical resistance and operational stability. J Chem Technol Biotechnol, 81:500-4.

Candelli M, Nista EC, Nestola M, et al. 2003. Saccharomyces cerevisiaeassociated diarrhea in an immunocompetent patient with ulcerative colitis. J Clin Gastroenterol, 36:39-40.

Caprilli R, Viscido A, Guagnozzi D. 2002. Review article: biological agents in the treatment of Crohn's disease. Aliment Pharmacol Ther, 16:1579-90.

Cetina-Sauri G, Sierra-Basto G. 1994. Therapeutic evaluation of Saccharomyces Boulardii in children with acute diarrhoea. Annales de Pediatrie, 41:397-400.

Chan AT, Giovannucci EL, Meyerhardt JA, et al. 2005. Long-term use of aspirin and nonsteroidal anti-inflammatory drugs and risk of colorectal cancer. JAMA, 294:914-23.

Chan FK, Chung S, Suen BY, et al. 2001. Preventing recurrent upper gastrointestinal bleeding in patients with Helicobacter pylori infection who are taking low-dose aspirin or naproxen. $N$ Engl J Med, 344:967-73.

Chande N, McDonald JW, MacDonald JK. 2006. Interventions for treating collagenous colitis. Cochrane Database Syst Rev, 4:CD003575.

Chang F, Deere H, Vu C. 2005. Atypical forms of microscopic colitis: morphological features and review of the literature. Adv Anat Pathol, 12:203-11.

Chang L. 2004. Review article: epidemiology and quality of life in functional gastrointestinal disorders. Aliment Pharmacol Ther, 20(Suppl 7):31-9.

Chang TM, Prakash S. 1997. Artificial cells for bioencapsulation of cells and genetically engineered E. coli. For cell therapy, gene therapy, and removal of urea and ammonia. Methods Mol Biol, 63:343-58.

Chapoy P. 1985. [Treatment of acute infantile diarrhea: controlled trial of Saccharomyces boulardii]. Ann Pediatr (Paris), 32:561-3.

Chassany O, Michaux A, Bergmann JF. 2000. Drug-induced diarrhoea. Drug Saf, 22:53-72.

Chatterjee A, Yasmin T, Bagchi D, et al. 2003. The bactericidal effects of Lactobacillus acidophilus, garcinol and Protykin compared to clarithromycin, on Helicobacter pylori. Mol Cell Biochem, 243:29-35.

Chen H, Ouyang W, Lawuyi B, et al. 2006a. A new method for microcapsule characterization: use of fluorogenic genipin to characterize polymeric microcapsule membranes. Appl Biochem Biotechnol, 134:207-22.

Chen H, Ouyang W, Lawuyi B, et al. 2005. Reaction of chitosan with genipin and its fluorogenic attributes for potential microcapsule membrane characterization. J Biomed Mater Res A, 75:917-27.

Chen H, Ouyang W, Lawuyi B, et al. 2006b. Genipin cross-linked alginatechitosan microcapsules: membrane characterization and optimization of cross-linking reaction. Biomacromolecules, 7:2091-8.

Chen ML, Ge Z, Fox JG, et al. 2006c. Disruption of tight junctions and induction of proinflammatory cytokine responses in colonic epithelial cells by Campylobacter jejuni. Infect Immun, 74:6581-9.

Chia SM, Wan AC, Quek CH, et al. 2002. Multi-layered microcapsules for cell encapsulation. Biomaterials, 23:849-56.

Chourasia MK, Jain SK. 2003. Pharmaceutical approaches to colon targeted drug delivery systems. J Pharm Pharm Sci, 6:33-66.

Chourasia MK, Jain SK. 2004. Potential of guar gum microspheres for target specific drug release to colon. J Drug Target, 12:435-42.

Colon AL, Madrigal JLM, Menchen LA, et al. 2004. Stress increases susceptibility to oxidative/nitrosative mucosal damage in an experimental model of colitis in rats. Dig Dis Sci, 49:1713-21.

Corfield AP, Myerscough N, Longman R, et al. 2000. Mucins and mucosal protection in the gastrointestinal tract: new prospects for mucins in the pathology of gastrointestinal disease. Gut, 47:589-94. 
Cremonini F, Di CS, Covino M, et al. 2002. Effect of different probiotic preparations on anti-helicobacter pylori therapy-related side effects: a parallel group, triple blind, placebo-controlled study. Am J Gastroenterol, 97:2744-9.

Crohn BB, Ginzburg L, Oppenheimer GD. 1952. Regional ileitis; a pathologic and clinical entity. Am J Med, 13:583-90.

Cruchet S, Obregon MC, Salazar G, et al. 2003. Effect of the ingestion of a dietary product containing Lactobacillus johnsonii La1 on Helicobacter pylori colonization in children. Nutrition, 19:716-21.

Cuvelier CA, Quatacker J, Mielants H, et al. 1993. M cells are damaged and increased in number in inflamed human ileal mucosa. Eur J Morphol, 31:87-91.

Czinn SJ, Nedrud JG. 1997. Immunopathology of Helicobacter pylori infection and disease. Springer Semin Immunopathol, 18:495-513.

D'Souza AL, Rajkumar C, Cooke J, et al. 2002. Probiotics in prevention of antibiotic associated diarrhoea: meta-analysis. BMJ, 324:1361.

Dautzenberg H, Schuldt U, Lerche D, et al. 1999a. Size exclusion properties of polyelectrolyte complex microcapsules prepared from sodium cellulose sulphate and poly[diallyldimethylammonium chloride]. J Memb Sci, 162:165-71.

Dautzenberg H, Schuldt U, Grasnick G, et al. 1999b. Development of cellulose sulfate-based polyelectrolyte complex microcapsules for medical applications. Ann N Y Acad Sci, 875:46-63.

de Gramont A, Tournigand C, Andre T, et al. 2006. Targeted agents for adjuvant therapy of colon cancer. Semin Oncol, 33(Suppl 11):42-5.

de Groot M, Schuurs TA, van Schilfgaarde R. 2004. Causes of limited survival of microencapsulated pancreatic islet grafts. J Surg Res, 121:141-50.

Debril MB, Renaud JP, Fajas L, et al. 2001. The pleiotropic functions of peroxisome proliferator-activated receptor gamma. J Mol Med, 79:30-47.

Dehni N, Schlegel RD, Cunningham C, et al. 1998. Influence of a defunctioning stoma on leakage rates after low colorectal anastomosis and colonic J pouch-anal anastomosis. Br J Surg, 85:1114-7.

Delia P, Sansotta G, Donato V, et al. 2002. Prevention of radiation-induced diarrhea with the use of VSL\#3, a new high-potency probiotic preparation. Am J Gastroenterol, 97:2150-2.

Doron S, Gorbach SL. 2006. Probiotics: their role in the treatment and prevention of disease. Expert Rev Anti Infect Ther, 4:261-75.

Dubuquoy L, Bourdon C, Peuchmaur M, et al. 2000. [Peroxisome proliferator-activated receptor (PPAR) gamma: a new target for the treatment of inflammatory bowel disease]. Gastroenterol Clin Biol, 24:719-24.

Duncan HD, Talbot IC, Silk DB. 1997. Collagenous colitis and cimetidine. Eur J Gastroenterol Hepatol, 9:819-20.

Egan LJ, Mays DC, Huntoon CJ, et al. 1999. Inhibition of interleukin1-stimulated NF-kappaB RelA/p65 phosphorylation by mesalamine is accompanied by decreased transcriptional activity. $J$ Biol Chem, 274:26448-53.

Everhart JE, Renault PF. 1991. Irritable bowel syndrome in office-based practice in the United States. Gastroenterology, 100:998-1005.

Fajas L, Debril MB, Auwerx J. 2001. Peroxisome proliferator-activated receptor-gamma: from adipogenesis to carcinogenesis. $J \mathrm{Mol}$ Endocrinol, 27:1-9.

Faubion WA Jr, Loftus EV Jr, Harmsen WS, et al. 2001. The natural history of corticosteroid therapy for inflammatory bowel disease: a populationbased study. Gastroenterology, 121:255-60.

Faure M, Moennoz D, Montigon F, et al. 2005. Dietary threonine restriction specifically reduces intestinal mucin synthesis in rats. $J$ Nutr, 135:486-91.

Fernandez-Banares F, Esteve M, Espinos JC, et al. 2006. Drug consumption and the risk of microscopic colitis. Am J Gastroenterol, 102:324-30.

Fiocchi C. 1998. Inflammatory bowel disease: Etiology and pathogenesis. Gastroenterology, 115:182-205.

Floch MH. 2003. Probiotics, irritable bowel syndrome, and inflammatory bowel disease. Curr Treat Options Gastroenterol, 6:283-88.
Galdeano CM, Perdigon G. 2004. Role of viability of probiotic strains in their persistence in the gut and in mucosal immune stimulation. $J$ Appl Microbiol, 97:673-81.

Galdeano CM, Perdigon G. 2006. The probiotic bacterium Lactobacillus casei induces activation of the gut mucosal immune system through innate immunity. Clin Vaccine Immunol, 13:219-26.

Galvez J, Coelho G, Crespo ME, et al. 2001. Intestinal anti-inflammatory activity of morin on chronic experimental colitis in the rat. Aliment Pharmacol Ther, 15:2027-39.

Gaserod O, Sannes A, Skjak-Braek G. 1999. Microcapsules of alginatechitosan. II. A study of capsule stability and permeability. Biomaterials, 20:773-83.

Ge Z, Feng Y, Taylor NS, et al. 2006. Colonization dynamics of altered Schaedler flora is influenced by gender, aging, and Helicobacter hepaticus infection in the intestines of Swiss Webster mice. Appl Environ Microbiol, 72:5100-3.

Goessling W, Mayer RJ. 2006. Systemic treatment of patients who have colorectal cancer and inflammatory bowel disease. Gastroenterol Clin North Am, 35:713-27.

Goldin BR. 1986. In situ bacterial metabolism and colon mutagens. Annu Rev Microbiol, 40:367-93.

Gonzalez CA, Salas-Salvado J. 2006. The potential of nuts in the prevention of cancer. Br J Nutr, 96(Suppl 2):S87-S94.

Gotteland M, Poliak L, Cruchet S, et al. 2005. Effect of regular ingestion of Saccharomyces boulardii plus inulin or Lactobacillus acidophilus LB in children colonized by Helicobacter pylori. Acta Paediatr, 94:1747-51

Grigorescu G, Rehor A, Hunkeler D. 2002. Polyvinylamine hydrochloridebased microcapsules: polymer synthesis, permeability and mechanical properties. J Microencapsul, 19:245-59.

Grothey A, Goldberg RM. 2004. A review of oxaliplatin and its clinical use in colorectal cancer. Expert Opin Pharmacother, 5:2159-70.

Gruner JS, Sehon JK, Johnson LW. 2002. Diagnosis and management of enterovesical fistulas in patients with Crohn's disease. Am Surg, 68:714-9.

Guandalini S. 2006. Probiotics for children: use in diarrhea. J Clin Gastroenterol, 40:244-8.

Häcker H, Redecke V, Blagoev B, et al. 2006. Specificity in Toll-like receptor signalling through distinct effector functions of TRAF3 and TRAF6. Nature, 439:204-7.

Hahm KB, Im YH, Parks TW, et al. 2001. Loss of transforming growth factor beta signalling in the intestine contributes to tissue injury in inflammatory bowel disease. Gut, 49:190-8.

Halpern GM, Prindiville T, Blankenburg M, et al. 1996. Treatment of irritable bowel syndrome with Lacteol Fort: a randomized, double-blind, cross-over trial. Am J Gastroenterol, 91:1579-85.

Hathaway LJ, Kraehenbuhl JP. 2000. The role of M cells in mucosal immunity. Cell Mol Life Sci, 57:323-32.

Heaney RP. 2006. Calcium intake and disease prevention. Arq Bras Endocrinol Metabol, 50:685-93.

Ho JG, Greco A, Rupnik M, et al. 2005. Crystal structure of receptor-binding C-terminal repeats from Clostridium difficile toxin A. Proc Natl Acad Sci U S A, 102:18373-8.

Hochain P, Capet C, Colin R. 2000. [Digestive complications of aspirin]. Rev Med Interne, 21(Suppl 1):50s-59s.

Hollenbach E, Neumann M, Vieth M, et al. 2004. Inhibition of p38 MAP kinase- and RICK/NF-kappaB-signaling suppresses inflammatory bowel disease. FASEB J. 18:1550-2.

Hollenbach E, Vieth M, Roessner A, et al. 2005. Inhibition of RICK/nuclear factor-kappaB and $\mathrm{p} 38$ signaling attenuates the inflammatory response in a murine model of Crohn disease. J Biol Chem, 280:14981-8.

Hortelano G, Al-Hendy A, Ofosu FA, et al. 1996. Delivery of human factor IX in mice by encapsulated recombinant myoblasts: a novel approach towards allogeneic gene therapy of hemophilia B. Blood, 87:5095-103.

Huang JS, Bousvaros A, Lee JW, et al. 2002. Efficacy of probiotic use in acute diarrhea in children: a meta-analysis. Dig Dis Sci, 47:2625-34. 
Hur C, Chan AT, Tramontano AC, et al. 2006. Coxibs versus combination NSAID and PPI therapy for chronic pain: an exploration of the risks, benefits, and costs. Ann Pharmacother, 40:1052-63.

Inadomi JM, Fennerty MB, Bjorkman D. 2003. Systematic review: the economic impact of irritable bowel syndrome. Aliment Pharmacol Ther, 18:671-82.

Inan A, Sen M, Koca C, et al. 2006. The effect of purified micronized flavonoid fraction on the healing of anastomoses in the colon in rats. Surg Today, 36:818-22.

Ishiguro M, Iida S, Uetake H, et al. 2006. Effect of combined therapy with low-dose 5-Aza-2'-deoxycytidine and irinotecan on colon cancer cell line HCT-15. Ann Surg Oncol, 14:1752-62.

Isolauri E, Kirjavainen PV, Salminen S. 2002. Probiotics: a role in the treatment of intestinal infection and inflammation? Gut, 50(Suppl 3): III54-III59.

Jaskowski TD, Litwin CM, Hill HR. 2006. Analysis of serum antibodies in patients suspected of having inflammatory bowel disease. Clin Vaccine Immunol, 13:655-60.

Jemal A, Siegel R, Ward E, et al. 2006. Cancer statistics, 2006. CA Cancer J Clin, 56106-30.

Kabelitz D, Medzhitov R. 2007. Innate immunity - cross-talk with adaptive immunity through pattern recognition receptors and cytokines. Curr Opin Immunol, 19:1-3.

Karin M, Delhase M. 2000. The I kappa B kinase (IKK) and NF-kappa B: key elements of proinflammatory signalling. Semin Immunol, 12:85-98.

Karin M, Yamamoto Y, Wang QM. 2004. The IKK NF-kappa B system: a treasure trove for drug development. Nat Rev Drug Discov, 3:17-26.

Kelly JP, Kaufman DW, Jurgelon JM, et al. 1996. Risk of aspirin-associated major upper-gastrointestinal bleeding with enteric-coated or buffered product. Lancet, 348:1413-16.

Kim HJ, Camilleri M, McKinzie S, et al. 2003. A randomized controlled trial of a probiotic, VSL\#3, on gut transit and symptoms in diarrhoeapredominant irritable bowel syndrome. Aliment Pharmacol Ther, 17:895-904.

Kim YG, Moon JT, Lee KM, et al. 2006. [The effects of probiotics on symptoms of irritable bowel syndrome]. Korean J Gastroenterol, 47:413-19.

Klinkenberg G, Lystad KQ, Levine DW, et al. 2001. pH-controlled cell release and biomass distribution of alginate-immobilized Lactococcus lactis subsp. lactis. J Appl Microbiol, 91:705-14.

Koh WP, Yuan JM, Van Den BD, et al. 2006. Peroxisome proliferatoractivated receptor (PPAR) gamma gene polymorphisms and colorectal cancer risk among Chinese in Singapore. Carcinogenesis, 27:1797-802.

Kotowska M, Albrecht P, Szajewska H. 2005. Saccharomyces boulardii in the prevention of antibiotic-associated diarrhoea in children: a randomized double-blind placebo-controlled trial. Aliment Pharmacol Ther, 21:583-590.

Kovacs-Nolan J, Mine Y. 2005. Microencapsulation for the gastric passage and controlled intestinal release of immunoglobulin Y. J Immunol Methods, 296:199-209.

Kunz AN, Noel JM, Fairchok MP. 2004. Two cases of Lactobacillus bacteremia during probiotic treatment of short gut syndrome. J Pediatr Gastroenterol Nutr, 38:457-8.

Kurtovic J, Segal I. 2004. Recent advances in biological therapy for inflammatory bowel disease. Trop Gastroenterol, 25:9-14.

Lacik I, Brissova M, Anilkumar AV, et al. 1998. New capsule with tailored properties for the encapsulation of living cells. J Biomed Mater Res, 39:52-60.

Lamprecht A, Yamamoto H, Takeuchi H, et al. 2005. Nanoparticles enhance therapeutic efficiency by selectively increased local drug dose in experimental colitis in rats. J Pharmacol Exp Ther, 315:196-202.

Lanas A, Ferrandez A. 2006. NSAID-induced gastrointestinal damage: current clinical management and recommendations for prevention. Chin J Dig Dis, 7:127-33.

Lanas AI. 2001. Current approaches to reducing gastrointestinal toxicity of low-dose aspirin. Am J Med, 110:70S-73S.
Langman MJ, Allan RN. 1999. Escherichia coli for ulcerative colitis. Lancet, 354:2000-1.

Lanza FL. 1998. A guideline for the treatment and prevention of NSAIDinduced ulcers. Members of the Ad Hoc Committee on Practice Parameters of the American College of Gastroenterology. Am J Gastroenterol, 93:2037-46.

Larsson SC, Giovannucci E, Wolk A. 2006. Folate intake, MTHFR polymorphisms, and risk of esophageal, gastric, and pancreatic cancer: a meta-analysis. Gastroenterology, 131:1271-83.

Lazenby AJ. 2005. Collagenous and lymphocytic colitis. Semin Diagn Pathol, 22:295-300.

Le PS, Kwiatkowski F, Paulin C, et al. 2006. In vitro thermochemotherapy of colon cancer cell lines with irinotecan alone and combined with mitomycin C. Hepatogastroenterology 53:693-7.

Leong RW, Chan FK. 2006. Drug-induced side effects affecting the gastrointestinal tract. Expert Opin Drug Saf, 5:585-92.

Lewis JD, Lichtenstein GR, Stein RB, et al. 2001. An open-label trial of the PPAR-gamma ligand rosiglitazone for active ulcerative colitis. Am J Gastroenterol, 96:3323-8.

Lichtenberger LM. 1995. The hydrophobic barrier properties of gastrointestinal mucus. Annu Rev Physiol, 57:565-83.

Lim F, Sun AM. 1980. Microencapsulated islets as bioartificial endocrine pancreas. Science, 210:908-10.

Lin $\mathrm{HC}$, Su BH, Chen AC, et al. 2005. Oral probiotics reduce the incidence and severity of necrotizing enterocolitis in very low birth weight infants. Pediatrics, 115:1-4.

Liu H, Yang XG, Nie SF, et al. 2007. Chitosan-based controlled porosity osmotic pump for colon-specific delivery system: Screening of formulation variables and in vitro investigation. Int $J$ Pharm, 332:115-24.

Louw JA, Marks IN. 1999. The treatment of peptic ulcer disease. Curr Opin Gastroenterol, 15:497.

Luca G, Nastruzzi C, Calvitti M, et al. 2005. Accelerated functional maturation of isolated neonatal porcine cell clusters: in vitro and in vivo results in NOD mice. Cell Transplant, 14:249-61.

Ma X, Vacek I, Sun A. 1994. Generation of alginate-poly-L-lysinealginate (APA) biomicrocapsules : the relationship between the membrane strength and the reaction conditions. Artif Cells Blood Substit Immobil Biotechnol, 22:43-69.

MacCallum A, Hardy SP, Everest PH. 2005. Campylobacter jejuni inhibits the absorptive transport functions of Caco-2 cells and disrupts cellular tight junctions. Microbiology, 151:2451-8.

MacDermott RP. 1996. Alterations of the mucosal immune system in inflammatory bowel disease. J Gastroenterol, 31:907-16.

Mackay AD, Taylor MB, Kibbler CC, et al. 1999. Lactobacillus endocarditis caused by a probiotic organism. Clin Microbiol Infect, 5:290-2.

Madden JA, Hunter JO. 2002. A review of the role of the gut microflora in irritable bowel syndrome and the effects of probiotics. Br J Nutr, 88(Suppl 1):S67-S72.

Mahipal A, Anderson KE, Limburg PJ, et al. 2006. Nonsteroidal antiinflammatory drugs and subsite-specific colorectal cancer incidence in the Iowa women's health study. Cancer Epidemiol Biomarkers Prev, 15:1785-90.

Malamut G, Cabane C, Dubuquoy L, et al. 2006. No evidence for an involvement of the p38 and JNK mitogen-activated protein in inflammatory bowel diseases. Dig Dis Sci, 51:1443-53.

Mamdani M, Warren L, Kopp A, et al. 2006. Changes in rates of upper gastrointestinal hemorrhage after the introduction of cyclooxygenase- 2 inhibitors in British Columbia and Ontario. CMAJ, 175:1535-8.

Marok R, Winyard PG, Coumbe A, et al. 1996. Activation of the transcription factor nuclear factor-kappaB in human inflamed synovial tissue. Arthritis Rheum, 39:583-91.

Marx J. 2007. Puzzling out the pains in the gut. Science, 315:33-5.

Massi M, Ioan P, Budriesi R, et al. 2006. Effects of probiotic bacteria on gastrointestinal motility in guinea-pig isolated tissue. World $J$ Gastroenterol, 12:5987-94. 
Mastretta E, Longo P, Laccisaglia A, et al. 2002. Effect of Lactobacillus GG and breast-feeding in the prevention of rotavirus nosocomial infection. J Pediatr Gastroenterol Nutr, 35:527-31.

Mattar AF, Drongowski RA, Coran AG, et al. 2001. Effect of probiotics on enterocyte bacterial translocation in vitro. Pediatr Surg Int, $17: 265-8$.

McIntosh GH, Royle PJ, Playne MJ. 1999. A probiotic strain of L. acidophilus reduces DMH-induced large intestinal tumors in male Sprague-Dawley rats. Nutr Cancer, 35:153-9.

Mei LH, Yao SJ. 2002. Cultivation and modelling of encapsulated Saccharomyces cerevisiae in NaCS-PDMDAAC polyelectrolyte complexes. J Microencapsul, 19:397-405.

Michetti P. 2004. Experimental Helicobacter pylori infection in humans: a multifaceted challenge. Gut, 53:1220-1.

Munkholm P, Langholz E, Davidsen M, et al. 1994. Frequency of glucocorticoid resistance and dependency in Crohn's disease. Gut, 35:360-2.

Neutra M, Forstner J. 1987. Gastrointestinal Mucus: Synthesis, Secretion and Function. New York, NY: Raven Press.

Niedzielin K, Kordecki H, Birkenfeld B. 2001. A controlled, double-blind, randomized study on the efficacy of Lactobacillus plantarum $299 \mathrm{~V}$ in patients with irritable bowel syndrome. Eur J Gastroenterol Hepatol, 13:1143-7.

Niyogi SK, Saha MR, De SP. 1994. Enteropathogens associated with acute diarrhoeal diseases. Indian J Public Health, 38:29-32.

Nobaek S, Johansson ML, Molin G, et al. 2000. Alteration of intestinal microflora is associated with reduction in abdominal bloating and pain in patients with irritable bowel syndrome. Am J Gastroenterol, 95:1231-8.

Nurdin N, Canaple L, Bartkowiak A, et al. 2000. Capsule permeability via polymer and protein ingress/egress. Science, 75:1165-75.

O’Mahony L, McCarthy J, Kelly P, et al. 2005. Lactobacillus and bifidobacterium in irritable bowel syndrome: symptom responses and relationship to cytokine profiles. Gastroenterology, 128:541-51.

O'Sullivan MA, O'Morain CA. 2000. Bacterial supplementation in the irritable bowel syndrome. A randomised double-blind placebocontrolled crossover study. Dig Liver Dis, 32:294-301.

Ohtani T, Hiroi A, Sakurane M, et al. 2003. Slow acetylator genotypes as a possible risk factor for infectious mononucleosis-like syndrome induced by salazosulfapyridine. Br J Dermatol, 148:1035-9.

Orive G, Bartkowiak A, Lisiecki S, et al. 2005. Biocompatible oligochitosans as cationic modifiers of alginate/Ca microcapsules. J Biomed Mater Res B Appl Biomater, 74:429-39.

Orive G, Hernandez RM, Gascon AR, et al. 2003a. Survival of different cell lines in alginate-agarose microcapsules. Eur J Pharm Sci, 18:23-30.

Orive G, Hernandez RM, Gascon AR, et al. 2003b. Development and optimisation of alginate-PMCG-alginate microcapsules for cell immobilisation. Int J Pharm, 259:57-68.

Ouwehand AC, Salminen SJ. 1998. The effects of cultured milk products with viable and non-viable bacteria. Int Dairy J, 8:749-58

Peleg II, Lubin MF, Cotsonis GA, et al. 1996. Long-term use of nonsteroidal antiinflammatory drugs and other chemopreventors and risk of subsequent colorectal neoplasia. Dig Dis Sci, 411319-26.

Peleg II, Maibach HT, Brown SH, et al. 1994. Aspirin and nonsteroidal anti-inflammatory drug use and the risk of subsequent colorectal cancer. Arch Intern Med, 154:394-9.

Peran L, Camuesco D, Comalada M, et al. 2005. Preventative effects of a probiotic, Lactobacillus salivarius ssp. salivarius, in the TNBS model of rat colitis. World J Gastroenterol, 11:5185-92.

Peura DA. 2004. Prevention of nonsteroidal anti-inflammatory drugassociated gastrointestinal symptoms and ulcer complications. Am J Med, 117(Suppl 5A):63S-71S.

Pierik M, Rutgeerts P, Vlietinck R, et al. 2006. Pharmacogenetics in inflammatory bowel disease. World J Gastroenterol, 12:3657-67.

Prakash S, Chang TM. 1996. Microencapsulated genetically engineered live E. coli DH5 cells administered orally to maintain normal plasma urea level in uremic rats. Nat Med, 2:883-7.
Prakash S, Chang TM. 2000. In vitro and in vivo uric acid lowering by artificial cells containing microencapsulated genetically engineered E. coli DH5 cells. Int J Artif Organs, 23:429-35.

Prakash S, Jones ML. 2005. Artificial cell therapy: New strategies for the therapeutic delivery of live bacteria. J Biomed Biotechnol, 2005:44-56.

Quaranta V, Weaver AM, Cummings PT, et al. 2005. Mathematical modeling of cancer: the future of prognosis and treatment. Clin Chim Acta, 357:173-9.

Quek CH, Li J, Sun T, et al. 2004. Photo-crosslinkable microcapsules formed by polyelectrolyte copolymer and modified collagen for rat hepatocyte encapsulation. Biomaterials, 25:3531-40.

Ramakers JD, Verstege MI, Thuijls G, et al. 2007. The PPARgamma agonist rosiglitazone impairs colonic inflammation in mice with experimental colitis. J Clin Immunol, 27:275-83.

Rao G. 1997. Aspirin preparation and risk of GI bleeding. J Fam Pract, 44:242-3.

Rautio M, Jousimies-Somer H, Kauma H, et al. 1999. Liver abscess due to a Lactobacillus rhamnosus strain indistinguishable from L. rhamnosus strain GG. Clin Infect Dis, 28:1159-60.

Reeves MJ, Newcomb PA, Trentham-Dietz A, et al. 1996. Nonsteroidal anti-inflammatory drug use and protection against colorectal cancer in women. Cancer Epidemiol Biomarkers Prev, 5:955-60.

Reinisch W, Gasche C, Wyatt J, et al. 1995. Steroid dependency in Crohn's disease. Lancet, 345:859.

Rembacken BJ, Snelling AM, Hawkey PM, et al. 1999. Non-pathogenic Escherichia coli versus mesalazine for the treatment of ulcerative colitis: a randomised trial. Lancet, 354:635-9.

Retsky MW, Swartzendruber DE, Wardwell RH, et al. 1990. Is Gompertzian or exponential kinetics a valid description of individual human cancer growth? Med Hypotheses, 33:95-106.

Rhodes JM, Campbell BJ. 2002. Inflammation and colorectal cancer: IBDassociated and sporadic cancer compared. Trends Mol Med, 8:10-6.

Riquelme AJ, Calvo MA, Guzman AM, et al. 2003. Saccharomyces cerevisiae fungemia after Saccharomyces boulardii treatment in immunocompromised patients. J Clin Gastroenterol, 36:41-3.

Rodriguez-Moranta F, Castells A. 2005. Mechanisms of colon cancer prevention with and beyond COX-2 inhibition. Curr Top Med Chem, 5:505-16.

Rokstad AM, Holtan S, Strand B, et al. 2002. Microencapsulation of cells producing therapeutic proteins: optimizing cell growth and secretion. Cell Transplant, 11:313-24.

Ross CJ, Ralph M, Chang PL. 2000. Somatic gene therapy for a neurodegenerative disease using microencapsulated recombinant cells. Exp Neurol, 166:276-86.

Saavedra JM, Bauman NA, Oung I, et al. 1994. Feeding of Bifidobacterium bifidum and Streptococcus thermophilus to infants in hospital for prevention of diarrhoea and shedding of rotavirus. Lancet, 344:1046-9.

Salazar-Lindo E, Miranda-Langschwager P, Campos-Sanchez M, et al. 2004. Lactobacillus casei strain GG in the treatment of infants with acute watery diarrhea: a randomized, double-blind, placebo controlled clinical trial [ISRCTN67363048]. BMC Pediatr, 4:18.

Salminen S, von Wright A, Morelli L, et al. 1998. Demonstration of safety of probiotics - a review. Int J Food Microbiol, 44:93-106.

Sambanis A. 2003. Encapsulated islets in diabetes treatment. Diabetes Technol Ther, 5:665-8.

Sandborn WJ. 2001. Transcending conventional therapies: the role of biologic and other novel therapies. Inflamm Bowel Dis, 7(Suppl 1): S9-16.

Sandler RS, Golden AL. 1986. Epidemiology of Crohn's disease. J Clin Gastroenterol, 8:160-5.

Sandor F, Buc M. 2005. Toll-like receptors. II. Distribution and pathways involved in TLR signalling. Folia Biol (Praha), 51:188-97.

Sartor RB. 2004. Therapeutic manipulation of the enteric microflora in inflammatory bowel diseases: antibiotics, probiotics, and prebiotics. Gastroenterology, 126:1620-33. 
Sastre M, Dewachter I, Rossner S, et al. 2006. Nonsteroidal antiinflammatory drugs repress beta-secretase gene promoter activity by the activation of PPARgamma. Proc Natl Acad Sci U S A, 103:443-48.

Schett G, Tohidast-Akrad M, Smolen JS, et al. 2000. Activation, differential localization, and regulation of the stress-activated protein kinases, extracellular signal-regulated kinase, c-JUN N-terminal kinase, and p38 mitogen-activated protein kinase, in synovial tissue and cells in rheumatoid arthritis. Arthritis Rheum, 43:2501-12.

Scholmerich J. 2006. Inflammatory bowel disease: Pandora's box, present and future. Ann N Y Acad Sci, 1072:365-78.

Schreiber S. 1998. Experimental immunomodulatory therapy of inflammatory bowel disease. Neth J Med, 53:S24-S31.

Sefton MV, May MH, Lahooti S, et al. 2000. Making microencapsulation work: conformal coating, immobilization gels and in vivo performance. $J$ Control Release, 65:173-86.

Sen S, Mullan MM, Parker TJ, et al. 2002. Effect of Lactobacillus plantarum $299 \mathrm{v}$ on colonic fermentation and symptoms of irritable bowel syndrome. Dig Dis Sci, 47:2615-20.

Serp D, Cantana E, Heinzen C, et al. 2000. Characterization of an encapsulation device for the production of monodisperse alginate beads for cell immobilization. Biotechnol Bioeng, 70:41-53.

Shanahan F. 2000. Probiotics and inflammatory bowel disease: Is there a scientific rationale? Inflamm Bowel Dis, 6:107-15.

Shanahan F. 2005. Physiological basis for novel drug therapies used to treat the inflammatory bowel diseases I. Pathophysiological basis and prospects for probiotic therapy in inflammatory bowel disease. Am J Physiol Gastrointest Liver Physiol, 288:G417-G421.

Sheu BS, Cheng HC, Kao AW, et al. 2006. Pretreatment with Lactobacillusand Bifidobacterium-containing yogurt can improve the efficacy of quadruple therapy in eradicating residual Helicobacter pylori infection after failed triple therapy. Am J Clin Nutr, 83:864-9.

Sibilia J, Ravaud P, Marck G. 2003. [Digestive and hemorrhage complications of low-dose aspirin]. Presse Med, 32:S17-S28.

Simon GL, Gorbach SL. 1984. Intestinal flora in health and disease. Gastroenterology, 86:174-93.

Slattery ML, Murtaugh MA, Sweeney C, et al. 2005. PPARgamma, energy balance, and associations with colon and rectal cancer. Nutr Cancer, 51:155-61.

Sokolowska M, Kowalski ML, Pawliczak R. 2005. [Peroxisome proliferator-activated receptors-gamma (PPAR-gamma) and their role in immunoregulation and inflammation control]. Postepy Hig Med Dosw (Online), 59:472-84.

Spreux A, Rodriguez A, Chichmanian RM. 1993. [Case reports on druginduced chronic diarrhea. An often unrecognized etiology?] Therapie, 48:494-5.

Stenson WF. 1994. Inflammatory mediators in inflammatory bowel disease. Curr Opin Gastroenterol, 10:384-9.

Strand BL, Morch YA, Espevik T, et al. 2003. Visualization of alginate-polyL-lysine-alginate microcapsules by confocal laser scanning microscopy. Biotechnol Bioeng, 82:386-94.

Sun Y, Ma X, Zhou D, et al. 1996. Normalization of diabetes in spontaneously diabetic cynomologus monkeys by xenografts of microencapsulated porcine islets without immunosuppression. $J$ Clin Invest, 98:1417-22.

Sung J, Russell R, Yeomans N, et al. 2000. Non-steroidal anti-inflammatory drug toxicity in the upper gastrointestinal tract. $J$ Gastroenterol Hepatol, 15(Suppl):G58-G68.

Sung JJ, Chung SC, Ling TK, et al. 1995. Antibacterial treatment of gastric ulcers associated with Helicobacter pylori. $N$ Engl J Med, 332:139-42.

Szajewska H, Kotowska M, Mrukowicz JZ, et al. 2001. Efficacy of Lactobacillus GG in prevention of nosocomial diarrhea in infants. J Pediatr, 138:361-5.

Tejpar S, Van Cutsem E. 2002. Molecular and genetic defects in colorectal tumorigenesis. Best Pract Res Clin Gastroenterol, 16:171-85.

ten Hove T, van den BB, Pronk I, et al. 2002. Dichotomal role of inhibition of p38 MAPK with SB 203580 in experimental colitis. Gut, 50:507-12.
Teshima D, Hino B, Makino K, et al. 2003. Sulphasalazine-induced leucopenia in a patient with renal dysfunction. $J$ Clin Pharm Ther, 28:239-42.

Thibault H, Aubert-Jacquin C, Goulet O. 2004. Effects of long-term consumption of a fermented infant formula (with Bifidobacterium breve c50 and Streptococcus thermophilus 065) on acute diarrhea in healthy infants. J Pediatr Gastroenterol Nutr, 39:147-52.

Thiele K, Bierhaus A, Autschbach F, et al. 1999. Cell specific effects of glucocorticoid treatment on the NF-kappaBp65/IkappaBalpha system in patients with Crohn's disease. Gut, 45:693-704.

Thoreux K, Schmucker DL. 2001. Kefir milk enhances intestinal immunity in young but not old rats. $J$ Nutr, 131:807-12.

Tromm A, Niewerth U, Khoury M, et al. 2004) The probiotic E. coli strain Nissle 1917 for the treatment of collagenous colitis: first results of an open-label trial. Z Gastroenterol, 42:365-9.

Urbanska A, Ouyang W, Bhathena J, et al. 2006. Investigation of the viability of microencapsulated live Lactobacillus acidophilus cells for their use in probiotic yogurts. Int J Prebiotics Probiotics, 1:33-7.

Ushiyama A, Tanaka K, Aiba Y, et al. 2003. Lactobacillus gasseri OLL2716 as a probiotic in clarithromycin-resistant Helicobacter pylori infection. J Gastroenterol Hepatol, 18:986-91.

Vallbacka JJ, Nobrega JN, Sefton MV. 2001. Tissue engineering as a platform for controlled release of therapeutic agents: implantation of microencapsulated dopamine producing cells in the brains of rats $J$ Control Release, 72:93-100.

van Raamsdonk JM, Cornelius RM, Brash JL, et al. 2002. Deterioration of polyamino acid-coated alginate microcapsules in vivo. J Biomater Sci Polym Ed, 13:863-84.

van Hogezand RA, Verspaget HW. 1996. Selective immunomodulation in patients with inflammatory bowel disease - Future therapy or reality? Neth J Med, 48:64-7.

Velin D, Bachmann D, Bouzourene H, et al. 2005. Mast cells are critical mediators of vaccine-induced Helicobacter clearance in the mouse model. Gastroenterology, 129:142-55.

Vinderola CG, Duarte J, Thangavel D, et al. 2005. Immunomodulating capacity of kefir. J Dairy Res, 72:195-202.

Vinderola G, Perdigon G, Duarte J, et al. 2006. Effects of kefir fractions on innate immunity. Immunobiology, 211:149-56.

Viswanathan VK, Hecht G. 2000. Innate immunity and the gut. Curr Opin Gastroenterol, 16:546-51.

VSL Pharmaceuticals, Inc. 2007. VSL 3 3: A Clear Answer for Symptom Relief: Designed for the dietary management of ulcerative colitis (UC), irritable bowel syndrome (IBS), or an ileal pouch. Accessed on December 12, 2007. URL: http://www.vsl3.com/VSL3/ default.asp.

Waetzig GH, Seegert D, Rosenstiel P, et al. 2002. p38 mitogen-activated protein kinase is activated and linked to TNF-alpha signaling in inflammatory bowel disease. J Immunol, 168:5342-51.

Wahl C, Liptay S, Adler G, et al. 1998. Sulfasalazine: a potent and specific inhibitor of nuclear factor kappa B. J Clin Invest, 101:1163-74.

Watts P, Smith A. 2005. TARGIT technology: coated starch capsules for site-specific drug delivery into the lower gastrointestinal tract. Expert Opin Drug Deliv, 2:159-67.

Weizman Z, Asli G, Alsheikh A. 2005. Effect of a probiotic infant formula on infections in child care centers: comparison of two probiotic agents. Pediatrics, 115:5-9.

Wen-tao Q, Ying Z, Juan M, et al. 2006. Optimization of the cell seeding density and modeling of cell growth and metabolism using the modified Gompertz model for microencapsulated animal cell culture. Biotechnol Bioeng, 93:887-95.

Werling D, Jungi TW. 2003. TOLL-like receptors linking innate and adaptive immune response. Vet Immunol Immunopathol, 91:1-12.

Whorwell PJ, Altringer L, Morel J, et al. 2006. Efficacy of an encapsulated probiotic Bifidobacterium infantis 35624 in women with irritable bowel syndrome. Am J Gastroenterol, 101:1581-90.

Wildt S, Madsen JL, Rumessen JJ. 2006a. Small-bowel permeability in collagenous colitis. Scand J Gastroenterol, 41:1044-9. 
Wildt S, Munck LK, Vinter-Jensen L, et al. 2006b. Probiotic treatment of collagenous colitis: a randomized, double-blind, placebo-controlled trial with Lactobacillus acidophilus and Bifidobacterium animalis subsp. Lactis. Inflamm Bowel Dis, 12:395-401.

Xu W, Liu L, Charles IG. 2002. Microencapsulated iNOS-expressing cells cause tumor suppression in mice. FASEB J, 16:213-5.

Yan F, Polk DB. 2006. Probiotics as functional food in the treatment of diarrhea. Curr Opin Clin Nutr Metab Care, 9:717-21.

Yang L, Chu JS, Fix JA. 2002. Colon-specific drug delivery: new approaches and in vitro/in vivo evaluation. Int J Pharm, 235:1-15.

Yao S, Guan Y, Lin D. 2006. Mass transfer behavior of solutes in NaCS-PDMDAAC capsules. Ind Eng Chem Res, 45:1811-16.

Yilmaz S, Bayan K, Dursun M, et al. 2007. Does adding misoprostol to standard intravenous proton pump inhibitor protocol improve the outcome of aspirin/NSAID-induced upper gastrointestinal bleeding?: a randomized prospective study. Dig Dis Sci, 52:110-8.
Yin C, Mien CS, Hoon QC, et al. 2003. Microcapsules with improved mechanical stability for hepatocyte culture. Biomaterials, 24:1771-80.

Zhang J, Yao SJ, Ying XJ, et al. 2005. [Immobilization of cells by macro-porous NaCS-PDMDAAC capsules and cultivation in shaking flask and bubble bioreactor]. Sheng Wu Gong Cheng Xue Bao, 21:633-7.

Zhang X, Wang W, Xie Y, et al. 2006. Proliferation, viability, and metabolism of human tumor and normal cells cultured in microcapsule. Appl Biochem Biotechnol, 134:61-76.

Zhang ZW, Dorrell N, Wren BW, et al. 2002. Helicobacter pylori adherence to gastric epithelial cells: a role for non-adhesin virulence genes. $J$ Med Microbiol, 51:495-502.

Zhu JH, Wang XW, Ng S, et al. 2005. Encapsulating live cells with water-soluble chitosan in physiological conditions. J Biotechnol, 117:355-65. 